\title{
Comparison of carbon-stock changes, eddy- covariance carbon fluxes and model estimates in coastal Douglas-fir stands in British Columbia
}

\author{
Colin J Ferster ${ }^{1 *}$, JA (Tony) Trofymow ${ }^{2,4}$, Nicholas C Coops' ${ }^{1}$ Baozhang Chen ${ }^{1}$ and Thomas Andrew Black ${ }^{3}$
}

\begin{abstract}
Background: The global network of eddy-covariance (EC) flux-towers has improved the understanding of the terrestrial carbon (C) cycle, however, the network has a relatively limited spatial extent compared to forest inventory data and plots. Developing methods to use inventory-based and EC flux measurements together with modeling approaches is necessary evaluate forest $C$ dynamics across broad spatial extents.

Methods: Changes in $C$ stock change $(\Delta C)$ were computed based on repeated measurements of forest inventory plots and compared with separate measurements of cumulative net ecosystem productivity ( $($ NEP) over four years (2003 - 2006) for Douglas-fir (Pseudotsuga menziesii var menziesii) dominated regeneration (HDF00), juvenile (HDF88 and HDF90) and near-rotation (DF49) aged stands (6, 18, 20, 57 years old in 2006, respectively) in coastal British Columbia. $\Delta C$ was determined from forest inventory plot data alone, and in a hybrid approach using inventory data along with litter fall data and published decay equations to determine the change in detrital pools. These $\Delta \mathrm{C}$-based estimates were then compared with $\Sigma$ NEP measured at an eddy-covariance flux-tower (EC-flux) and modelled by the Carbon Budget Model - Canadian Forest Sector (CBM-CFS3) using historic forest inventory and forest disturbance data. Footprint analysis was used with remote sensing, soils and topography data to evaluate how well the inventory plots represented the range of stand conditions within the area of the flux-tower footprint and to spatially scale the plot data to the area of the EC-flux and model based estimates.
\end{abstract}

Results: The closest convergence among methods was for the juvenile stands while the largest divergences were for the regenerating clearcut, followed by the near-rotation stand. At the regenerating clearcut, footprint weighting of CBM-CFS3 $\Sigma$ NEP increased convergence with EC flux $\Sigma N E P$, but not for $\triangle C$. While spatial scaling and footprint weighting did not increase convergence for $\Delta C$, they did provide confidence that the sample plots represented site conditions as measured by the EC tower.

Conclusions: Methods to use inventory and EC flux measurements together with modeling approaches are necessary to understand forest $\mathrm{C}$ dynamics across broad spatial extents. Each approach has advantages and limitations that need to be considered for investigations at varying spatial and temporal scales.

Keywords: Forest carbon; Micrometeorology; Biometry; Remote sensing; Geographic information systems

\footnotetext{
* Correspondence: colin.ferster@ubc.ca

'Department of Forest Resources Management, University of British

Columbia, 2424 Main Mall, Vancouver, BC V6T 1Z4, Canada

Full list of author information is available at the end of the article
} 


\section{Background}

Forests are a large component of the global carbon $(\mathrm{C})$ stocks, containing an estimated $1146 \mathrm{Pg} \mathrm{C}$ (Dixon et al. 1994). Forest processes, which may be influenced by forest management, can therefore have a large impact on the global $\mathrm{C}$ budget, either by storing or releasing $\mathrm{C}$. It is therefore critical to understand forest $\mathrm{C}$ dynamics, including forest $\mathrm{C}$ stock components and transfer mechanisms in order to develop accurate forest $\mathrm{C}$ models such as the Carbon Budget Model of the Canadian Forest Sector (CBM-CFS3) (Kurz et al. 2009), 3PG (Landsberg and Waring 1997), and Ecosys (Grant et al. 2007), amongst others, as well as to inform forest management policy and for national and international reporting (Kurz et al. 2002). Factors affecting forest $\mathrm{C}$ dynamics include natural (e.g. fire, insect outbreaks) and anthropogenic disturbances from land use management and change (e.g. harvest, reforestation, deforestation) (Kurz et al. 2002) as well as weather (Morgenstern et al. 2004), fertilization (Jassal et al. 2010), and stand age and species composition, which can be related to disturbance history, site edaphic characteristics, or management practices (e.g. silvicuture) (Humphreys et al. 2006; Krishnan et al. 2009).

To measure the net exchange of $\mathrm{C}$ between land ecosystems and the atmosphere (net ecosystem exchange, NEE, with -NEE referred to as net ecosystem productivity, NEP), a global network of over 400 eddy-covariance (EC) flux stations has been established across a range of ecosystems, building an extensive data record of NEP, in some cases spanning up to two decades. The majority of these towers are located on sites not undergoing major disturbances so the fluxes measured reflect the interaction of weather, vegetation composition, stand age, and seasonal phenology. EC flux-towers use micrometeorological equipment to take measurements at the canopy scale of the exchanges of gasses including $\mathrm{CO}_{2}$, water vapor, sensible heat, and some are equipped to measure other trace gases (Baldocchi 2008). The source area contributing to measurements made by the instruments mounted on the EC flux-tower, the flux-tower footprint, is variable in size and shape depending on height of measurement, surface roughness length, wind speed and direction, and atmospheric stability (Leclerc and Thurtell 1990; Schmid 2002), and proper interpretation of EC fluxtower based measurements depends on the flux-footprint over which the fluxes are sampled (Chen et al. 2008). Early estimates modelled flux-footprints as simple ovals. Recently, estimates of flux-footprint climatology may demonstrate more complex geometries and continuous probability density surfaces to quantify the upwind distribution of weighting factors over long time periods (Chen et al. 2009).

Forest measurements can be taken to quantify forest $\mathrm{C}$ stocks (Dixon et al. 1994; Clark and Brown 2001; NFI
2008), and by measuring forest $C$ stocks at two times with a sufficient interval between measurements, the $\mathrm{C}$ stock change $(\Delta \mathrm{C})$ can be determined and used to estimate the cumulative net uptake of $\mathrm{C}$ from the atmosphere to the forest for the period of measurement ( NEP) (Clark and Brown 2001). Measurements are typically made of individual plants, for example, all trees within a plot are measured for diameter, species, and height, then allometric relationships are used to determine tree mass (Ter-Mikaelian 1997). Similarly, woody debris pieces are measured along transects using line intersect sampling and allometric relationships are applied to find biomass (Brown 1971). Other components are made by direct measurements, for example, understory vegetation can be sampled, dried, and weighed (Bailey et al. 1998). To measure soil C, field samples are typically dried and weighed for calculation of bulk density, and sent for laboratory analysis of $\mathrm{C}$ using dry combustion (Janzen 2005). Soil C measurements are important because the underground processes driving soil respiration form a large component of ecosystem gas exchanges, but these are less well-understood and measured compared to above ground stocks and processes (Ehman et al. 2002). Changes in soil $\mathrm{C}$ storage over time have implications as a source or sink for the global $\mathrm{C}$ cycle, and as an indicator of environmental function and health (Janzen 2005).

One application of forest measurement data to provide accounting of forest management actions and subsequently inform forest management decisions is as an input to $\mathrm{C}$ budget models such as CBM-CFS3. CBM-CFS3 is a forest $\mathrm{C}$ budget model that utilizes growth and yield information for biomass and generates explicit simulation of dead organic matter dynamics (Kurz et al. 2009). In contrast, forest process models use approaches based on the understanding of processes such as photosynthesis; these process-based models have more potential to model changing conditions because they do not rely on historic growth and yield and therefore are better suited to simulate forest conditions under global change situations (Landsberg and Waring 1997). CBM-CFS3 was designed to meet reporting requirements for forest management, provide policy support, and a function as a $\mathrm{C}$ budgeting tool for operating foresters, thus functioning at a range of spatial scales, and estimating records of C stocks, transfers between pools, and emissions (Kurz et al. 2002; Kurz et al. 2009).

Comparing EC flux-tower cumulative NEP ( $\Sigma$ NEP) and inventory ground plot measurements of $\mathrm{C}$ stock changes $(\Delta C)$ over the same period can help inform forest $C$ processes for several reasons. First, ground plot measurements can serve as an independent validation of $\Sigma$ NEP measurements made at EC flux-towers. Second, inventory plot data can provide more detailed information about the stand structural changes that may be 
driving variation stand-level EC C exchange. Third, broad stand inventory measurement datasets are available for a greater spatial extent than the global EC flux-tower network. For example, the Canadian National Forest Inventory (NFI) samples approximately 22,000 photo plots locations across Canada with detailed ground plots measured at over 1000 locations (Gillis et al. 2005). However, comparing inventory plot changes and EC flux-tower measurements requires comparisons to be made across different spatial and temporal scales. Therefore, such comparisons pose methodological challenges beyond individual inventory plot and EC flux-tower measurements.

Comparisons between EC tower measurements of $\Sigma \mathrm{NEP}$ and inventory plot measurements of $\Delta C$ stocks have been completed at a number of sites globally (Schulze et al. 2000; Granier et al. 2000; Law et al. 2001; Barford et al. 2001; Ehman et al. 2002; Curtis et al. 2002; Miller et al. 2004; Black et al. 2005; Gough et al. 2008; Kominami et al. 2008; Yashiro et al. 2010; Gielen et al. 2013; Babst et al. 2014), and at two sites of the Canadian Carbon Program (CCP), Boreal Ecosystems Research and Monitoring Sites (BERMS) station, located in the boreal forest of northern Saskatchewan (Theede 2007). Over a ten-year interval (1994 - 2004), Theede (2007) found a convergence of $15.6 \pm 4.0 \mathrm{MgC} \mathrm{ha}^{-1} 10^{-1}$ years (inventory plots) and 18.2 $\pm 8.09 \mathrm{MgC} \mathrm{ha}^{-1} 10^{-1}$ years (EC tower) at the Old Aspen site and $5.8 \pm 2.0 \mathrm{MgC} \mathrm{ha}^{-1} 10^{-1}$ years (inventory plots) and $6.9 \pm 1.6 \mathrm{MgC} \mathrm{ha}^{-1} 10^{-1}$ years (EC tower) at the Old Jack Pine site. However, the homogeneous stand structure contributing to canopy-level EC flux measurements and large fetch in the boreal forest reduced the need for consideration of spatial vegetation structure and footprint distributions.

These previous studies have contributed considerably to the understanding of forest $\mathrm{C}$ dynamics; however, at sites with more complex vegetation structure and topography, such as the forests found in coastal British Columbia, the spatial distribution of vegetation structure and the footprint distribution are important considerations for accurate comparisons of EC flux-tower and inventory plot measurements (Schmid and Lloyd 1999). More complex ecosystems, therefore, require more complex models and methods developed for accurate comparisons of EC fluxtower measurements and inventory-based measurements. For example, a limited number of studies, including Ehman et al. (2002), Chen et al. (2009), Ferster et al. (2011), and Gielen et al. (2013) applied weighting by EC flux-tower footprint climatology to inventory-based measurements, where areas of the footprint that contribute more to tower-measured flux are weighted more heavily than other areas, resulting in an overall improvement when compared to simple flux footprint geometries.

In this paper, the difference between 2002 and 2006 inventory plot measurements of ecosystem $\mathrm{C}$ stocks was determined and the $\Delta \mathrm{C}$ stocks compared to CBM-CFS3 modelled and EC-flux-tower estimates of $\Sigma$ NEP at the CCP coastal British Columbia Flux Station. Through a combination of variable topography and a complex disturbance history (Trofymow et al. 2008), the EC fluxtower sites possess fine-scale spatial variation in forest structure, thus presenting a challenge to the interpretation of EC flux data (Schmid and Lloyd 1999; Göckede et al. 2004). To allow the comparison between measurements from the inventory plots, $\mathrm{C}$ budget models, and EC flux-towers, our approach consisted of four steps: first, we found the change in $\mathrm{C}$ based on forest inventory ground plot measurements made in 2002 and 2006 (four year period); second, we developed an additional approach that utilized litterfall data and published decay equations, for a second inventory-based estimate of $\mathrm{C}$ stocks change; third, we defined stand attributes at a fine spatial resolution, stratified the site based on stand attributes, and weighted the two inventory plot estimates; and fourth, calculated $\Delta \mathrm{C}$. These were compared with CBM-CFS3 model-based estimates of $\Sigma$ NEP and EC flux-tower-measured $\Sigma$ NEP for four years (2003, 2004, 2005 and 2006) in the same period. Finally, we evaluated how the forest age and conditions at the different sites accounted for convergence or lack of convergence in estimates for the different methods, and discussed the relative advantages and constraints of each measurement method.

\section{Methods}

\section{Study area}

The coastal British Columbia Flux Station sites are located on the leeward central east coast of Vancouver Island (Figure 1), in the Coastal Western Hemlock biogeoclimatic zone (Green and Klinka 1994) with a mean annual air temperature of $10^{\circ}$ Celsius. Douglas-fir (Pseudotsuga menziesii var menziesii (Mirb.) Franco) is the dominant species, with lesser amounts of western hemlock (Tsuga heterophylla (Raf.) Sarg.), western redcedar (Thuja plicata Donn ex D. Donn), and red alder (Alnus rubra Bong.). Three eddy-covariance and meteorological towers were placed in stands of different ages (Table 1).

EC flux-tower footprints, which delineate the spatial distribution of upwind source-weighting factors, were calculated by Chen et al. (2009) to represent the size, shape, direction, and magnitude of the flux as a function of wind speed and direction, measurement height, and surface roughness. Chen et al. (2009) calculated hourly footprints for $10 \mathrm{~m}$ by $10 \mathrm{~m}$ cells, weighted by NEP, and averaged over the 2002 - 2006 measurement period to determine the footprint climatology for the sites. In this study, the flux-footprint climatology $85 \%$ cumulative flux probability boundary was selected as the maximum extent of analysis, since the majority of the probability 


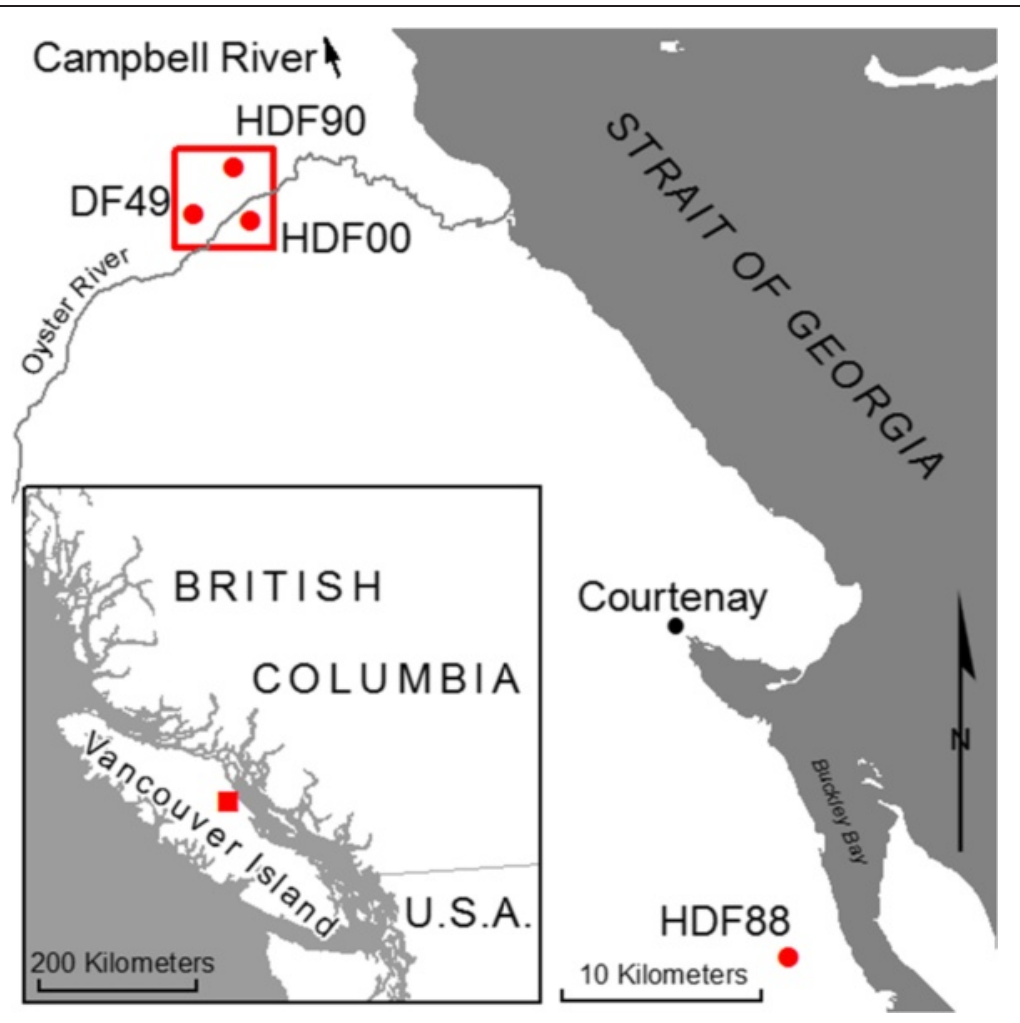

Figure 1 The Canadian Carbon Program Coastal British Columbia Flux Station consists of three sites with flux towers (DF49, HDF00, HDF88) as well as ancillary inventory ground plots (HDF90) on the central east coast of Vancouver Island. A $5 \times 5 \mathrm{~km}$ area (red square) spanning the Oyster River area has been used for spatial modelling studies.

density is concentrated within this area and the remainder extends across a large area (Figure 2).

\section{Inventory ground plots}

All ground plots were established and measured by the Canadian Forest Service at the four sites following Canadian National Forest Inventory (NFI) guidelines and protocols (NFI 2008) though they are not part of the primary NFI ground plot network. Plot locations were chosen to represent each site series class (based on air photo interpretation and field transects) within the preliminary flux footprint boundary estimated in 2002 (Figure 2). Establishment and initial measurements were made in September 2002 and re-measurements were made in September 2006, constituting a four-year measurement interval. NFI data-compilation software used to determine plot-level values through application of allometric equations to overstory trees and density values for woody debris NFI (2008). Since live overstory vegetation roots were not measured in 2002 or 2006, coarse and fine root $\mathrm{C}$ mass was estimated from overstory biomass using equations by Li et al. (2003).

\section{Live biomass}

Live trees greater than $1.3 \mathrm{~m}$ tall were measured in an $11.28 \mathrm{~m}$ radius circular plot. Where trees were very numerous (for example, at HDF88), a half plot or $5 \mathrm{~m}$ radius circular plot was measured following NFI guidelines (NFI 2008). Allometric equations are used in the NFI compiler to estimate stem, bark, branch, and foliar biomass based on work by Lambert et al. (2005). These biomass values were converted to $\mathrm{C}$ content by assuming $52,56,52$, and $52 \%$ dry $\mathrm{C}$ concentration, respectively (Matthews 1993).

Understory vegetation from four $1 \mathrm{~m} \times 1 \mathrm{~m}$ microplots was destructively sampled and sent to the laboratory for drying and weighing for determination of mass which was converted to $\mathrm{C}$ content assuming $50 \%$ dry $\mathrm{C}$ concentration.

\section{Detritus}

Woody debris, fallen woody material $>1 \mathrm{~cm}$ diameter, was measured for diameter, species, and decay class along four $15 \mathrm{~m}$ transects at each plot. Decay class was determined by field crews in the five-class ordinal rating system 
Table 1 Study site locations and characteristics

\begin{tabular}{|c|c|c|}
\hline Site & $\begin{array}{l}\text { Location (latitude } \\
\text { and longitude) }\end{array}$ & Site description \\
\hline DF49 & $49.868797^{\circ}$ & $\begin{array}{l}\text { - Near-rotation stand established } \\
\text { in } 1949 .\end{array}$ \\
\hline \multirow[t]{6}{*}{ (Figure 2a) } & $-125.33515^{\circ}$ & - 162 ha flux tower footprint. \\
\hline & & - 12 ground plots. \\
\hline & & - 260 to 470 m elevation. \\
\hline & & $\begin{array}{l}\text { - Harvested of old growth timber } \\
\text { in } 1937,1938 \text {, and } 1943 .\end{array}$ \\
\hline & & $\begin{array}{l}\text { - Broadcast burned in } 1938 \text { and } 1943 \\
\text { following harvest. }\end{array}$ \\
\hline & & • Planted in 1949. \\
\hline HDF88 & $49.536655^{\circ}$ & $\begin{array}{l}\text { - Juvenile pole-sapling stand } \\
\text { established in } 1988 .\end{array}$ \\
\hline \multirow[t]{6}{*}{ (Figure 2b) } & $-124.90146^{\circ}$ & - 35 ha flux tower footprint. \\
\hline & & - 6 ground plots. \\
\hline & & - 150 to 220 m elevation. \\
\hline & & $\begin{array}{l}\text { - Harvested of second-growth } \\
\text { timber in } 1987 .\end{array}$ \\
\hline & & $\begin{array}{l}\text { - Broadcast burned following } \\
\text { harvest. }\end{array}$ \\
\hline & & • Planted in 1988. \\
\hline \multirow[t]{8}{*}{ HDF90 } & $49.893666^{\circ}$ & $\begin{array}{l}\text { - Juvenile pole-sapling stand } \\
\text { established in } 1990 .\end{array}$ \\
\hline & $-125.304415^{\circ}$ & - No flux tower. \\
\hline & & - 6 ground plots. \\
\hline & & • 175 m elevation. \\
\hline & & $\begin{array}{l}\text { - Harvested of second-growth } \\
\text { timber in } 1990 .\end{array}$ \\
\hline & & $\begin{array}{l}\text { - Broadcast burned following } \\
\text { harvest. }\end{array}$ \\
\hline & & • Planted in 1990. \\
\hline & & $\begin{array}{l}\text { - Similar in age and composition } \\
\text { to HDF88. }\end{array}$ \\
\hline HDFOO & $49.872177^{\circ}$ & $\begin{array}{l}\text { - Regenerating clearcut stand } \\
\text { established in } 2000 .\end{array}$ \\
\hline \multirow[t]{6}{*}{ (Figure 2c) } & $-125.29235^{\circ}$ & - 14 ha flux tower footprint. \\
\hline & & - 9 ground plots. \\
\hline & & - 160 to 190 m elevation. \\
\hline & & $\begin{array}{l}\text { - Harvested from a second-growth } \\
\text { stand in } 2000 .\end{array}$ \\
\hline & & $\begin{array}{l}\text { - Logging debris were piled and } \\
\text { burned. }\end{array}$ \\
\hline & & • Planted in 2000. \\
\hline
\end{tabular}

utilized by the NFI, from intact (Class 1 ) to highly decomposed (Class 5) (NFI 2008). NFI compilation routines utilize algorithms for line intercept sampling to determine plot level volume and a lookup table of woody debris density values by species and decay class to determine mass. C content was determined assuming 50\% dry C concentration of woody debris mass. Fine woody debris, fallen woody material $2 \mathrm{~mm}$ to $<1 \mathrm{~cm}$ diameter, was sampled from within the four $1 \times 1 \mathrm{~m}$ understory microplots in each sample plot and sent for laboratory drying, weighing, and determination of mass, and $\mathrm{C}$ content assuming dry mass is composed of $50 \% \mathrm{C}$. Dead standing trees were measured for diameter, height, and species and decay class was observed and recorded by field crews. Stumps were measured for diameter and decay class in 2002 but were not remeasured in 2006.

Surface substrates were measured along four $15 \mathrm{~m}$ long transects to determine the average depth and percent area surface coverage in the entire plot. The organic litter, fibric, and humus layer (forest floor) was sampled and average depths measured from within four $20 \times 20$ $\mathrm{cm}$ templates (one at each microplot). These destructive samples were collected, sieved, dried, and weighed to determine bulk density and subsamples sent for laboratory analysis of $\mathrm{C}$ concentration.

\section{Mineral soil}

In $2002,<2 \mathrm{~mm}$ mineral soil was sampled for bulk density and $\mathrm{C}$ concentrations from $10-12 \mathrm{~cm}$ diameter excavated holes at three depth intervals $0-15 \mathrm{~cm}$ (4 samples), $15-35 \mathrm{~cm}$ (2 samples), and $35-55 \mathrm{~cm}$ (one sample) and \% volumetric coarse fragments determined from one 55-cm-deep soil pit per ground plot. Data were scaled to the entire groundplot discounting for the area without mineral soil (i.e. exposed bedrock). In 2006, the 0-15 cm layer was re-measured for $\mathrm{C}$ content at four locations in each plot using a $2 \mathrm{~cm}$ diameter soil corer. Samples were stored in plastic bags at $2^{\circ} \mathrm{C}$ prior to laboratory processing. For a detailed description of soil sampling methods see NFI (2008). For 2002-2006 soil C stock changes, only the $0-15 \mathrm{~cm}$ layer was considered, soil $\mathrm{C}$ at deeper depths was assumed unchanged.

\section{Changes in inventory ground plot $\mathrm{C}$ stocks}

Changes in $\mathrm{C}$ stocks over the four-year interval were calculated from the difference between $C$ stocks in 2002 and 2006. The total change in $C$ stocks was calculated as:

$$
\Delta \mathrm{C}=\Delta \mathrm{C}_{\mathrm{L}}+\Delta \mathrm{C}_{\mathrm{D}}+\Delta \mathrm{C}_{\mathrm{S}}
$$

where $\Delta \mathrm{C}_{\mathrm{L}}$ is the change in total live biomass $\mathrm{C}$ stocks including live trees, and shrubs, herbs, and bryophytes; $\Delta C_{D}$ is the total change in detrital $\mathrm{C}$ stocks including dead standing trees, woody debris, and the forest floor; and $\Delta C_{S}$ is the change in mineral soil C stocks $(0-15 \mathrm{~cm})$. 


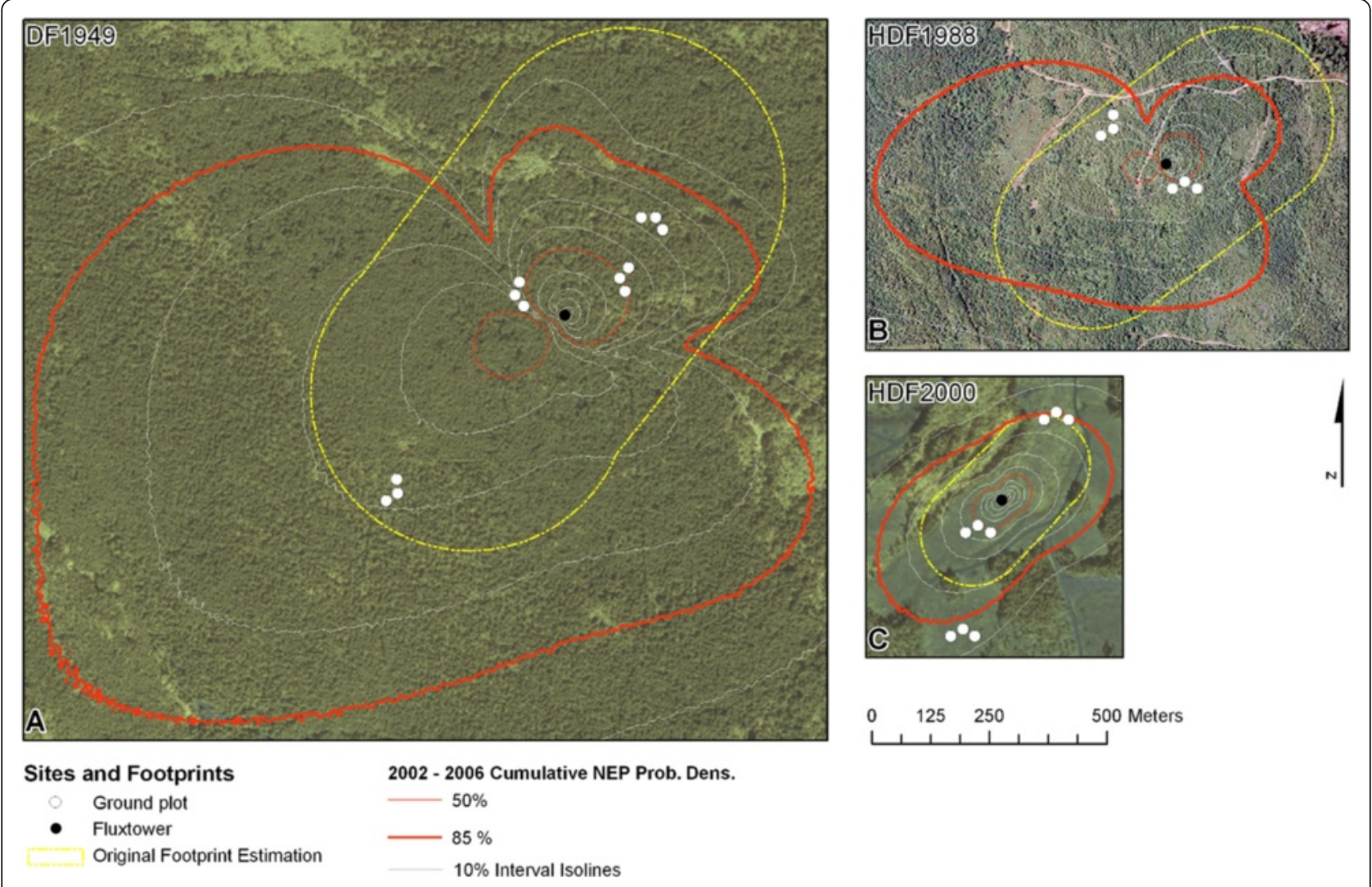

Figure 2 Flux footprints and inventory plot locations for the A) DF49, B) HDF88, C) HDF00 sites. Background imagery is pan-sharpened 2004 Quickbird for $\mathbf{A}$ and $\mathbf{C}$, and true-colour orthophoto for $\mathbf{B}$.

\section{$\Delta C_{D 2}$ Detritus annual accounting method}

Preliminary examination of the $\Delta C_{D}$ values showed larger-than-expected changes in the measured $\mathrm{C}$ stocks over the four-year interval, especially for the forest floor component. To evaluate these measured changes, $\Delta \mathrm{C}_{\mathrm{D}}$ was estimated using a second method (referred to as $\Delta \mathrm{C}_{\mathrm{D} 2}$ ) that accounted for the annual inputs into the detrital pools from litterfall and mortality (i.e. the transfers from live biomass to forest floor and soil, and live trees to dead trees respectively) and annual losses and transfers from decomposition estimated using published equations and parameters (Smyth et al. 2010; Kurz et al. 2009).

Inputs to detrital $C$ pools from 2002 - 2005 included overstory fine litterfall (needles, leaves, cones, twigs) which was collected quarterly in $30.189 \mathrm{~m}^{2}$ conicalmesh litterfall traps located in each ground plot at DF49, HDF88 and HDF90. Annual litter fall masses were calculated and converted to $\mathrm{C}$ assuming 50\% dry $\mathrm{C}$ content. Herbaceous material, which was not tall enough to be sampled using litterfall traps especially at the HDF00 site, was collected and measured at the sample plots in 2002 and 2006, linearly interpolated between measurement dates, and assumed to turn over at a rate of $80 \%$ annually. Shrubby litterfall material was divided into stem and branch and foliage components, and assumed to turn over at a rate of $3 \%$ and $95 \%$, respectively similar to the fine branch wood and foliage for deciduous trees (Kurz et al. 2009). When trees died within the measurement interval, the biomass was transferred to the detrital pools half way through the measurement interval. Finally, the biomass of any trees (live or dead) that were measured in 2002 and not recorded by the field crew in 2006 was transferred to the detrital pools half-way through the measurement interval under the assumption that the tree fell during the measurement interval.

Losses through decomposition and transfer to the soil organic $\mathrm{C}$ of each detrital pool was calculated at an annual time step with an annual average temperature of $10^{\circ} \mathrm{C}$ using coefficients that were developed and validated nationally (Smyth et al. 2010) for the CBM-CFS3 model (Kurz et al. 2009). The transfers and coefficients used are presented in Figure 3. Soil $\mathrm{C}$ stock changes were assumed negligible, and $\Delta \mathrm{C}_{2}$ was calculated as: $\Delta \mathrm{C}_{2}=\Delta \mathrm{C}_{\mathrm{L}}+\Delta \mathrm{C}_{\mathrm{D} 2}$. 


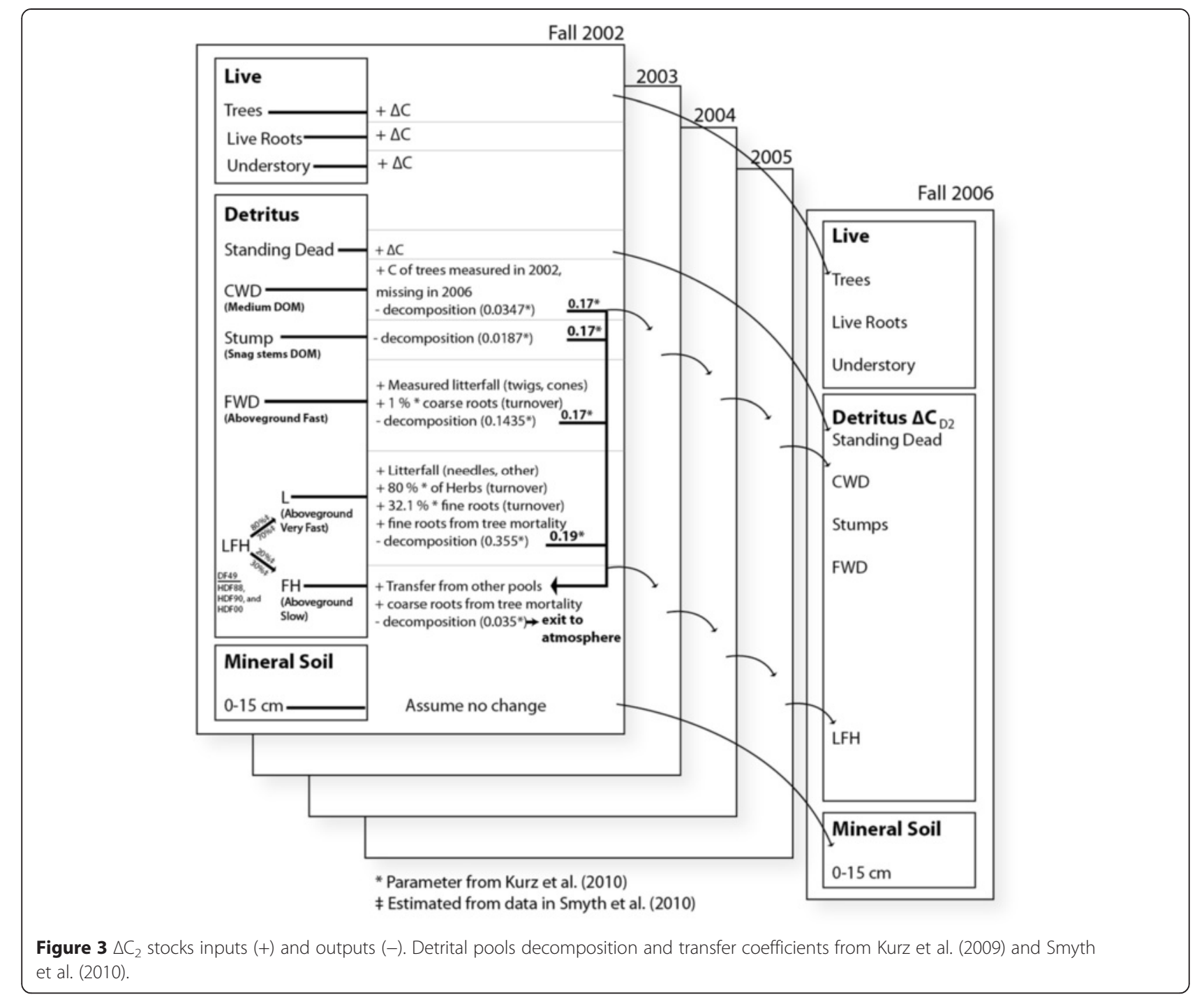

Spatial distribution of $\mathrm{C}$ stocks and $\Delta \mathrm{C}$ at the stand scale To account for spatial heterogeneity due to stand structure and topography, the methodology developed by Ferster et al. (2011) was applied to the ground plot data at the flux tower sites. Following this approach, predictor variables from GIS, topography, and remote sensing data were used to impute measurements from the inventory ground plots across the forest site based on the threemost-similar-neighbours (K-MSN with $\mathrm{K}=3$ ) (Crookston and Finley 2008) using the Mahalanobis distance as a measure of similarity (Mahalanobis 1936). For each footprint cell, the detailed inventory target measurements were estimated as the weighted mean of the three nearest neighbours (inversely weighted by the Mahalanobis distance) and used for calculation of sitelevel means of $\Delta C$. To assess the error of the model, the root mean squared difference (RMSD) was calculated based on leave-one-out cross validation (Stage and Crookston 2007). The procedure was completed using R version 2.11 ( $\mathrm{R}$ Development Core Team 2011) and yaImpute version 1.0-10 (Crookston and Finley 2008). Predictor variables were selected if correlations with inventory-based C stocks in 2002 and 2006 were significant at the $95 \%$ confidence level and there was no significant co-linearity with other predictor variables. Following the calculation, the 2002 - 2006 cumulative NEP footprint probability density surface for each site (calculated by Chen et al. 2008 and Chen et al. 2009) was used to weight each $10 \mathrm{~m}$ by $10 \mathrm{~m}$ footprint cell for the calculation of the site level mean value.

Site-level estimates of $\Delta C$ and $\Delta C_{2}$ stocks and were calculated three ways. First, inventory- based site estimates $\Delta C$ and $\Delta C_{2}$ stocks were calculated as an arithmetic mean of ground plots at each site. Second, $\Delta C_{2}$ stocks were calculated with the K-MSN prediction. Third, and finally, $\Delta \mathrm{C}_{2}$ stocks were calculated with the K-MSN prediction weighted by flux footprint probability density. 


\section{Flux tower $\Sigma$ NEP}

Measurement and calculations of flux tower annual NEP published by Black et al. (2008) and Krishnan et al. (2009) were summed to find the cumulative ¿NEP (2004-2006) used for this study. These values were gap filled for conditions at night when friction velocity was low (i.e. inadequate turbulent mixing) and corrected for energy-balance closure. Annual NEP values for 2003, 2004, 2005, and 2006 were summed for each site to estimate the $\Sigma$ NEP total for the four-year period. Morgenstern et al. (2004) reported that uncertainty in the annual NEP measured using EC at the near-rotation stand may be as much as $0.9 \mathrm{MgC} \mathrm{ha}^{-1}$ year $^{-1}$ (due to systematic error in the EC measurements). This suggests that the uncertainty in the estimate at the near-rotation stand may be $\pm 3.6 \mathrm{MgC} \mathrm{ha}^{-1}$ over the full four-year measurement interval. Detailed estimates of the uncertainty that propagates through the calculation based on the friction velocity thresholds (e.g. following Richardson and Hollinger 2007) was beyond the scope of this paper.

\section{CBM-CFS3 $\Sigma$ NEP}

CBM-CFS3 is a forest $\mathrm{C}$ accounting model used for national reporting of annual $\mathrm{C}$ inventories for Canada's managed forests (Kurz et al. 2009). This model uses growth and yield equations and allometric equations to estimate tree growth and stand net primary production (NPP). The $\mathrm{C}$ mass of overstory trees and overstory tree roots is use to estimate litterfall and root mortality transfers to the aboveground and belowground detritus C pools, respectively. A soil submodel estimates decomposition and heterotrophic respiration (Rh) based on the size of various detrital pools and mean annual temperature. The model tracks all major $\mathrm{C}$ pools to ensure closure and estimates annual NEP from NPP - Rh. Wang et al. (2011) modeled forest processes using the CBM-CFS3 model for the $5 \times 5 \mathrm{~km}$ area spanning the Oyster River and encompassing the DF49, HDF90, and HDF00 sites (Figure 1). Model runs for the area were performed on 1 hectare grid cells of forest disturbance history data, forest cover data, growth and yield equations, and disturbance transition matrices from Trofymow et al. (2008). The modeled $\Sigma$ NEP values for the DF49, HDF00 sites (from Wang et al. 2011) were calculated as site-level means unweighted and weighted by the flux probability distribution for the model cells in the footprint area; and at HDF90 as an unweighted mean of model cells over the spatial extent of the ground plots. Annual model values of NEP for 2003, 2004, 2005 and 2006 were summed to calculate the $\Sigma$ NEP and mean annual NEP for the four year period (Figure 4).

\section{Comparing convergence of $\triangle \mathrm{C}$, EC tower $\Sigma N E P$, and CBM- CFS3 $\Sigma$ NEP}

Comparisons were made among the estimates by first evaluating how each method ranked the stand ages. Second, estimates of EC tower $\Sigma$ NEP and CBM-CFS3 $\Sigma$ NEP were compared. Third, at each stand age from youngest to oldest, the estimates of $\triangle \mathrm{C}$ and tower and CBM-CFS3 $\Sigma \mathrm{NEP}$ were compared for convergence by comparing the means, variance around the means indicated by the standard deviation, and spatial variance indicated by the RMSD. Comparisons of convergence among methods were made for the following estimates: $\Delta C_{2}$ as an arithmetic mean of plots $\left(\Delta C_{2}\right.$ unweighted), $\Delta C_{2}$ with $\mathrm{K}$ MSN classification $\left(\Delta \mathrm{C}_{2}\right.$ K-MSN), $\Delta \mathrm{C}_{2}$ with K-MSN classification and footprint weighting $\left(\Delta \mathrm{C}_{2}\right.$ K-MSN FPW), CBM-CFS3 $\Sigma$ NEP as an arithmetic mean of cells within the tower footprint, CBM-CFS3 $\Sigma$ NEP as a footprint weighted mean ( $\Sigma$ NEP CBM-CFS3 FPW), and EC tower $\Sigma \mathrm{NEP}$.

\section{Results}

Live biomass $\Delta \mathrm{C}_{\mathrm{L}}$

For all sites, there was a positive change in the live $C$ mass of overstory trees (Table 2). For the near-rotation stand and juvenile stands, the increase was larger than at the regenerating site. The increase in live biomass $C$ was nearly equal at the near-rotation and juvenile stands. An increase in shrub, herb, and bryophyte understory $\Delta C$ was observed at the near rotation and regenerating stands, while a small decrease in understory $\Delta C$ stocks occured at the juvenile stands, possibly related to an expected increase in canopy closure as the overstory trees matured. Comparing the two juvenile stands (HDF88 and HDF90), HDF88 had higher live biomass $\mathrm{C}$ than HDF90 (for example, live stem $C$ and total live $C$ were more than 1 standard deviation larger).

\section{Detritus $\Delta C_{D 1}$}

Dead standing tree $C$ decreased in the near-rotation stand due to dead standing trees falling during the measurement interval, and there was a small increase at the other sites due to tree mortality (Table 2). Large woody debris increased in the near-rotation stand, and decreased at the other sites. There was considerable variability among plots, indicated by the high standard deviations compared to the means. Fine woody debris decreased at all sites, except one of the juvenile sites (where there was a small increase). The large decrease in fine woody debris at the regenerating clearcut was likely due to decomposition of debris from the recent harvest. Finally, forest floor material increased at all sites, with the smallest increase at the regenerating clearcut, and the largest increase at the juvenile stands. 


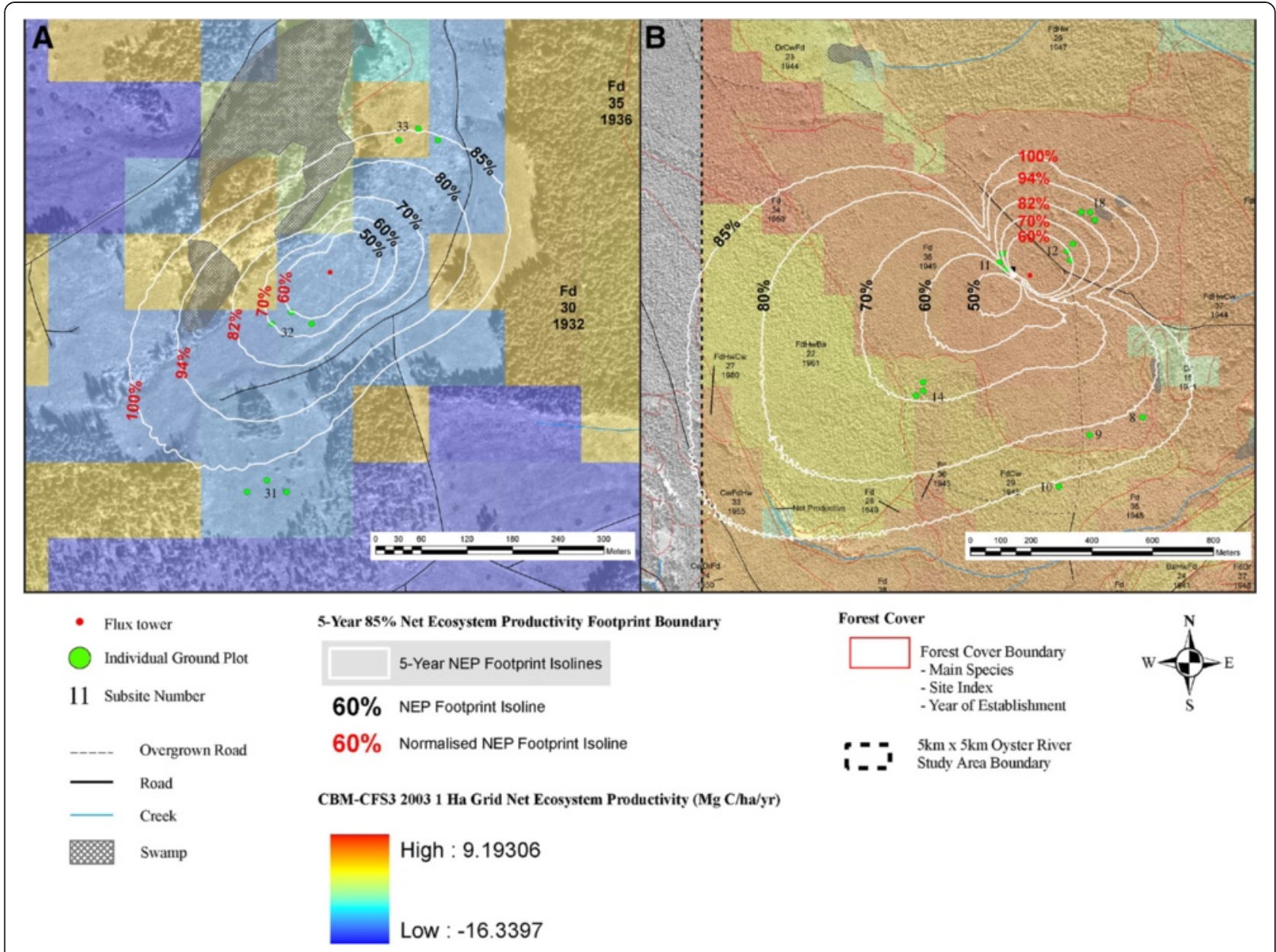

Figure 4 Flux tower footprint isolines and CBM-CFS3 model grids for a) the regenerating clearcut (HDF00) b) the near-rotation stand (DF49). For main species, $\mathrm{Fd}=$ Douglas-fir (Pseudotsuga menziesii), Hw = western hemlock (Tsuga heterophylla), Cw = western redcedar (Thuja plicata), Dr = red alder (Alnus rubra), $\mathrm{Ba}=$ Amabilis Fir (Abies amabilis). Site index is an estimation of height of typical dominant and co-dominant trees in even-aged and undisturbed sites at 50 years age to indicate productivity.

\section{Mineral soil $\Delta \mathrm{C}_{\mathrm{s}}$}

Soil C $(0-15 \mathrm{~cm})$ stocks was highest at the near-rotation site, followed by the two juvenile stands, and lowest at the regenerating clearcut (Table 2). Over the measurement interval, large increases in mineral soil $(0-15 \mathrm{~cm})$ $\Delta \mathrm{C}_{\mathrm{s}}$ were measured at all sites, with the highest at one of the juvenile stands (HDF88).

\section{Detritus annual accounting method $\Delta C_{D 2}$}

Measured litterfall was highest at the near-rotation stand, followed by the juvenile stands, and the regenerating stand had the lowest amount (Figure 5). The majority of litterfall at the near rotation stand and juvenile stands was needles followed by twigs. At the nearrotation stand, litterfall was highest in 2001-2002, decreased through 2004-2005, and slightly increased in 2005-2006. The other sites were relatively constant through time.
Results from the annual accounting method for detritus, showed a net gain for the sum of components at the near-rotation stand, and a decrease at the other sites (Table 3). The increase in $\mathrm{C}$ at the near-rotation stand was slightly larger using $\Delta C_{D 2}$ than the direct measurement method; however, the biggest difference was at the juvenile stand, which showed a net loss using $\Delta C_{\mathrm{D} 2}$, and a large positive balance using the direct measurement method. For stumps, this method indicated that decomposition may have been greater than was initially expected (stumps were not re-measured due to an expectation of minimal decomposition), especially at the more recently disturbed juvenile and regenerating clearcut sites. Large woody debris increased at the near-rotation stand, and decreased at the other sites, due to less dead standing trees to fall and less branchfall. The increase in fine woody debris was estimated to be much lower using $\Delta C_{D 2}$, with the near-rotation stand having a net-accumulation of fine 
Table 2 Inventory-based site $C$ stocks and $\Delta C$ estimates using arithmetic plot means (standard deviation)

\begin{tabular}{|c|c|c|c|c|}
\hline & DF49 & HDF90 & HDF88 & HDFOO \\
\hline \multicolumn{5}{|l|}{ Live } \\
\hline Foliage C 2002 & $12.7(1.8)$ & $2.7(0.9)$ & $2.6(0.8)$ & $0(0.1)$ \\
\hline Foliage $\Delta C$ & $-0.1(0.7)$ & $1.2(0.7)$ & $1.5(0.4)$ & $0.4(0.5)$ \\
\hline Branch C 2002 & $22.1(4)$ & $2.5(1)$ & $1.5(0.4)$ & $0(0.1)$ \\
\hline Branch $\Delta C$ & $0.7(1.2)$ & $1.3(0.9)$ & $1.8(0.5)$ & $0.1(0.2)$ \\
\hline Bark C 2002 & $17.6(3.8)$ & $0.7(0.1)$ & $1.1(0.4)$ & $0(0)$ \\
\hline Bark $\Delta C$ & $0.9(0.9)$ & $0.7(0.3)$ & $1(0.3)$ & $0.1(0.2)$ \\
\hline Stem C 2002 & $90.6(23.4)$ & $2.4(0.4)$ & $4.7(2)$ & $0.1(0.3)$ \\
\hline Stem $\Delta C$ & $5.7(4.7)$ & $3.3(1.1)$ & $4.4(1.3)$ & $0.6(1.1)$ \\
\hline Roots C 2002 & $32.6(8.3)$ & $1.8(0.3)$ & $2.8(1.3)$ & $0.1(0.1)$ \\
\hline Roots $\Delta C$ & $1.6(1.6)$ & $1.8(0.6)$ & $3.9(0.9)$ & $0.7(1.5)$ \\
\hline Understory C 2002 & $1.3(0.6)$ & $8.3(1.9)$ & $11.2(4.7)$ & $4.9(1.8)$ \\
\hline Understory $\Delta C$ & $1.3(1.8)$ & $-0.2(2.8)$ & $-2.6(4.5)$ & $1.7(1.9)$ \\
\hline Total Live C 2002 & 177 (39.9) & $18.5(3.7)$ & $24(4.7)$ & $5.2(2)$ \\
\hline Total Live $\Delta C$ & $10.2(8.7)$ & $8.1(6)$ & $10(5.9)$ & $3.7(4.4)$ \\
\hline \multicolumn{5}{|l|}{ Detritus } \\
\hline Standing Dead C 2002 & $21.8(13.9)$ & $0.2(0.2)$ & $0(0.1)$ & $0(0.2)$ \\
\hline Standing Dead $\Delta C$ & $-3.4(11.1)$ & $0.5(0.6)$ & $0.1(0.2)$ & $0(0.2)$ \\
\hline Stumps C 2002 & $6.4(3.2)$ & $5.7(2.8)$ & $11.7(6.1)$ & $11.9(10.6)$ \\
\hline Stumps $\Delta C$ & $0(0)$ & $0(0)$ & $0(0)$ & $0(0)$ \\
\hline Large Woody Debris C 2002 & $34.9(20.5)$ & $12.3(8.7)$ & $43.3(25.3)$ & $14.4(11.1)$ \\
\hline Large Woody Debris $\Delta C$ & $1.6(12.4)$ & $-3.5(9.7)$ & $-1.5(18.8)$ & $-0.9(6.3)$ \\
\hline Fine Woody Debris C 2002 & $3.1(1)$ & $1.3(0.7)$ & $0.5(0.6)$ & $6.1(2.9)$ \\
\hline Fine Woody Debris $\Delta C$ & $-0.9(1)$ & $-0.7(0.8)$ & $0.8(0.8)$ & $-4.5(2.6)$ \\
\hline Forest Floor C 2002 & $13.8(7.3)$ & $12.1(7.2)$ & $18.8(13.1)$ & $18.2(11.6)$ \\
\hline Forest Floor $\Delta C$ & $11(6.5)$ & $1.9(11.2)$ & $24.8(19.7)$ & $0.1(12.3)$ \\
\hline Total Detritus C 2002 & $79.9(32.7)$ & $31.6(8.4)$ & $74.4(38.7)$ & $50.6(16.8)$ \\
\hline Total Detritus $\Delta C$ & $8.2(21)$ & $-1.9(8.1)$ & $24.2(30.3)$ & $-5.4(12.6)$ \\
\hline \multicolumn{5}{|l|}{ Soil } \\
\hline Mineral Soil 0-15 cm C 2002 & $38.6(21.9)$ & $29(8.9)$ & $34.6(16.1)$ & $23.6(11.3)$ \\
\hline Mineral Soil 0-15 cm $\Delta C$ & $18.8(24.1)$ & $27.8(27.7)$ & $10.7(32.4)$ & $24.2(15.2)$ \\
\hline \multicolumn{5}{|l|}{ Totals } \\
\hline Total Live $\Delta C$ & $18.3(23.4)$ & $6.2(10.5)$ & $34.2(30.6)$ & $-1.7(14.9)$ \\
\hline \multicolumn{5}{|l|}{+ Total Detritus $\Delta C$} \\
\hline Total Live $\Delta C$ & $37.2(34.7)$ & $34(29.8)$ & $44.9(41.3)$ & $22.5(14.2)$ \\
\hline \multicolumn{5}{|l|}{+ Total Detritus $\Delta C$} \\
\hline + Mineral Soil $0-15 \mathrm{~cm} \Delta \mathrm{C}$ & & & & \\
\hline
\end{tabular}

woody debris, the juvenile sites had a small loss, and the regeneration site experienced the largest decrease. This indicates that, given the available inputs to litterfall and expected rates of decomposition for fine woody debris, the direct measured stock changes in fine woody debris was very likely unrealistically high. Finally, for the forest floor layer, the near-rotation stand was estimated to have a large increase, while the other sites decreased, with the greatest decrease at the regenerating clearcut.

Since the plot values for $\Delta C_{D 2}$ were judged more reliable, all subsequent analyses to spatially scale the plot data to the site were made using $\Delta C_{2}$. 


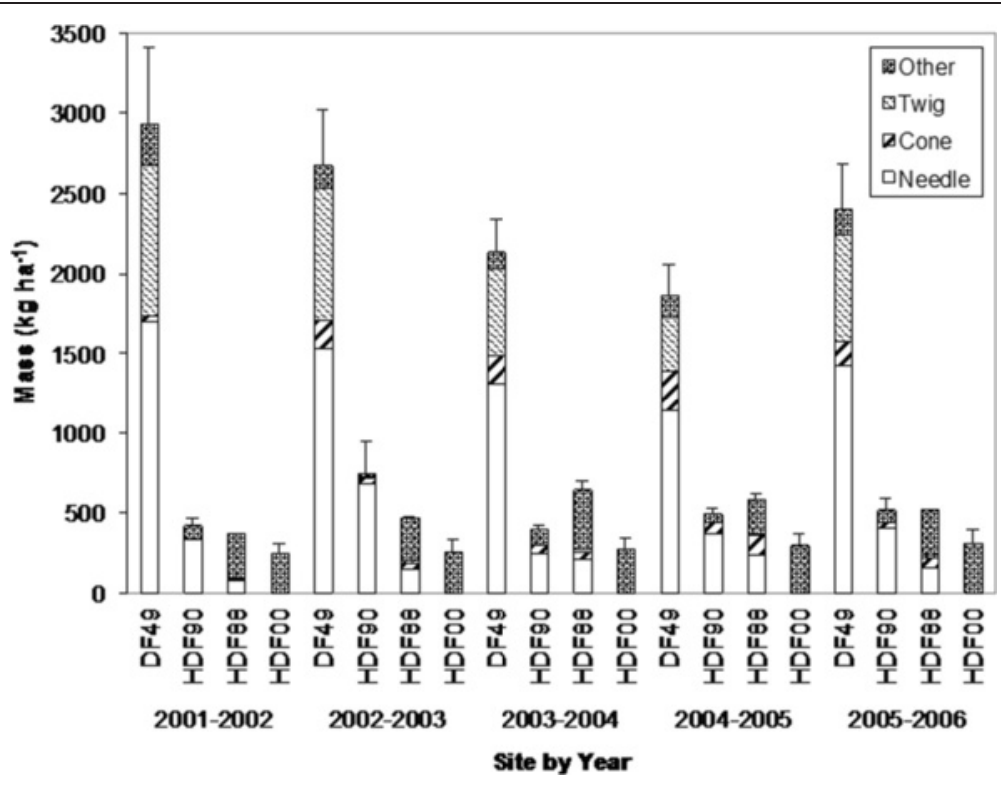

Figure 5 Measured annual litterfall 2001-2006. Needles include green and senescent foliage, cones include male and female cones, twigs include woody material such as twigs or small branches, and other includes miscellaneous pieces such as leaves, mosses, and lichens.

\section{Spatial distribution of $\mathrm{C}$ stocks and $\Delta \mathrm{C}_{2}$ stocks}

Predictor variables (Table 4) were selected and used for the K-MSN procedure at the sites with flux towers (Figure 6). Slope was an important predictor for all sites as it was strongly correlated with soil $C$ stocks (with less sloping plots having higher soil $(0-15 \mathrm{~cm}) \mathrm{C}$ stocks), and at the regenerating clearcut, slope was also correlated with living tree $C$ stocks. At the near rotation site, forest-inventory mapping was a significant predictor variable for overstory $C$ stocks. Due to the smaller footprints at the other sites, forest-inventory mapping varied little within the site; however, at all sites the other spatial predictor variables showed finer scale variation. At the regenerating clearcut, NDVI was a significant predictor for woody debris, forest floor, and mineral soil $\mathrm{C}$ stocks.

The Mahalanobis distance (Figure 7) demonstrates how comprehensively the inventory ground plots represent stand conditions across the footprint. Lower percentiles represent small distances that were relatively well represented by the ground plots. Areas with the smallest Mahalanobis distances and best ground plot representation were close to the towers in the areas contributing most to NEP measurements (within the 50\%

Table 3 Inventory-based site detrital $C$ in 2002 and $\Delta C_{D 2}$ (2002-2006) using plot mean (standard deviations) litterfall, mortality and decomposition values

\begin{tabular}{|c|c|c|c|c|}
\hline & DF49 & HDF90 & HDF88 & HDFOO \\
\hline \multicolumn{5}{|l|}{ Detritus } \\
\hline$C_{2002}$ Standing Dead & $21.8(13.9)$ & $0.2(0.2)$ & $0(0.1)$ & $0(0.2)$ \\
\hline$\Delta C_{D 2}$ Standing Dead & $-3.4(11.1)$ & $0.5(0.6)$ & $0.1(0.2)$ & $0(0.2)$ \\
\hline$C_{2002}$ Stumps & $6.4(3.2)$ & $5.7(2.8)$ & $11.7(6.1)$ & $11.9(10.6)$ \\
\hline$\Delta C_{D 2}$ Stumps $\Delta C$ & $-0.5(0.2)$ & $-0.4(0.2)$ & $-0.9(0.4)$ & $-0.9(0.8)$ \\
\hline$C_{2002}$ Large Woody Debris C & $34.9(20.5)$ & $12.3(8.7)$ & $43.3(25.3)$ & $14.4(11.1)$ \\
\hline$\Delta C_{D 2}$ Large Woody Debris & $3.9(9.6)$ & $-1(1)$ & $-4.3(2.6)$ & $-1.4(1)$ \\
\hline$C_{2002}$ Fine Woody Debris & $3.1(1)$ & $1.3(0.7)$ & $0.5(0.6)$ & $6.1(2.9)$ \\
\hline$\Delta C_{D 2}$ Fine Woody Debris & $1(0.8)$ & $-0.4(0.3)$ & $-0.1(0.2)$ & $-2.3(1.1)$ \\
\hline$C_{2002}$ Forest Floor & $13.8(7.3)$ & $12.1(7.2)$ & $18.8(13.1)$ & $18.2(11.6)$ \\
\hline$\Delta C_{D 2}$ Forest Floor & $8.2(4.1)$ & $-4.8(4.2)$ & $-7.4(7.2)$ & $-9.3(6.7)$ \\
\hline$C_{2002}$ Total Detritus & $79.9(32.7)$ & $31.6(8.4)$ & $74.4(38.7)$ & $50.6(16.8)$ \\
\hline$\Delta \mathrm{C}_{\mathrm{D} 2}$ Total Detritus & $9.2(8.7)$ & $-6.1(4.2)$ & $-12.5(9.4)$ & $-13.8(6.5)$ \\
\hline
\end{tabular}

All units are $\mathrm{Mg} \mathrm{Cha}{ }^{-1}$. 
Table 4 Environmental predictor variables used to determine stratification units at DF49, HDF88, and HDF00

\begin{tabular}{|c|c|c|c|c|c|}
\hline \multirow[b]{2}{*}{ Coverage } & \multirow[b]{2}{*}{ Variable } & \multirow[b]{2}{*}{ Units } & \multicolumn{3}{|l|}{ Selection } \\
\hline & & & DF49 & HDF88 & HDFOO \\
\hline \multirow[t]{2}{*}{ Forest-Inventory } & Site Index ${ }^{1}$ & $\mathrm{~m}$ & selected & & \\
\hline & Top Height & $\mathrm{m}$ & & & \\
\hline \multirow[t]{10}{*}{ Disturbance History (Trofymow et al. 2008) } & 1st Harvest & year & & & \\
\hline & 2nd Harvest & year & & & \\
\hline & 1st Fire & year & & & \\
\hline & 2nd Fire & year & & & \\
\hline & Date Est. 1953 & year & & & \\
\hline & Date Est. 2003 & year & & & \\
\hline & 1st Fertilization & year & & & \\
\hline & 2nd Fertilization & year & & & \\
\hline & Fire Cause 1 & nominal & & & \\
\hline & Fire Cause 2 & nominal & & & \\
\hline \multirow[t]{6}{*}{ Topography $^{3}$} & aspect & azimuth & selected & selected & selected \\
\hline & Elevation & $\mathrm{m}$ asl & & & selected \\
\hline & Slope & degrees & selected & selected & selected \\
\hline & $\operatorname{Scos} A^{2}$ & & & selected & selected \\
\hline & SSINA ${ }^{2}$ & & & selected & selected \\
\hline & TSRAI $^{2}$ & & selected & selected & selected \\
\hline 1999 Orthophoto & Dominant Canopy Tree Density & stems ha ${ }^{-1}$ & selected & selected & \\
\hline \multicolumn{6}{|l|}{ (Gougeon 1995) } \\
\hline 2004 Multispectral $^{4}$ & $\mathrm{NDVI}$ & NDVI & selected & & selected \\
\hline Forest-Inventory & Cover Species & & & & \\
\hline (Trofymow et al. 2008) & Site Species & & & & \\
\hline Soil Survey of Canada (Jungen 1985) & Most Common Soil Association & & & & \\
\hline CFS and Forest Companies & Site Series & & selected & selected & \\
\hline (Trofymow et al. 2008) & & & & & \\
\hline
\end{tabular}

${ }^{1}$ Site Index: Tree height at 50 years age at breast height $(1.3 \mathrm{~m})$.

${ }^{2}$ Topographic Variables: SCOSA = Slope $\times \cos \left(\right.$ Aspect), SSINA = Slope $\times \sin ($ Aspect $) ;$ TSRAI $($ Topographic Solar Radiation Aspect Index $)=\left(1-\cos \left(\left(\pi / 180^{\circ}\right)\left(\right.\right.\right.$ Aspect- $\left.\left.\left.30^{\circ}\right)\right)\right) / 2$ (Roberts and Cooper 1989).

${ }^{3}$ Topography from 2004 LiDAR survey at DF49 and HDF00 (Coops et al. 2007). Topography from 1:50,000 National Topographic Series map at HDF88.

${ }^{4}$ Multispectral data from 2004 Quickbird survey at DF49 and HDF00. Multispectral data from 2004 Landsat scene at HDF88.

cumulative flux probability density isoline). Notable areas with large Mahalanobis distances included areas with different forest cover types (e.g., patches of hardwoods at the near-rotation stand), very few overstory trees (at the juvenile stand), and short steep slopes (between bench terraces at the regenerating clearcut).

For site level estimations of $\Delta C_{L}$ at the regenerating clearcut, K-MSN was more than 1 standard deviation lower than the unweighted mean, and K-MSN-FPW was 1 standard deviation lower than K-MSN. For $\Delta C_{D 2}$, KMSN and K-MSN FPW were less than 1 standard deviation higher than the unweighted mean (Tables 3 and 5). The totals for $\Delta \mathrm{C}_{2}$ K-MSN and K-MSN FPW were less than 1 standard deviation higher than the arithmetic mean (Table 6).
For the juvenile stands, K-MSN and K-MSN FPW $\Delta \mathrm{C}_{\mathrm{L}}$ was less than 1 standard deviation higher than the unweighted mean. The K-MSN estimate was higher than the K-MSN FPW estimate. For $\Delta C_{D 2}$, K-MSN and KMSN FPW estimates were slightly higher than the mean (less than 1 standard deviation). For the total $\Delta C_{2}$, the estimates were less than 1 standard deviation different, and the standard deviations were very large compared to the means, indicating a large amount of variability at the site.

At the near-rotation stand, $\Delta \mathrm{C}_{\mathrm{L}} \mathrm{K}-\mathrm{MSN}$ and K-MSN FPW were slightly higher than the arithmetic mean (less than 1 standard deviation). The estimates using KMSN and KMSN-FPW were identical. For $\Delta C_{\mathrm{D} 2}$, the unweighted mean was higher than K-MSN and K-MSN 

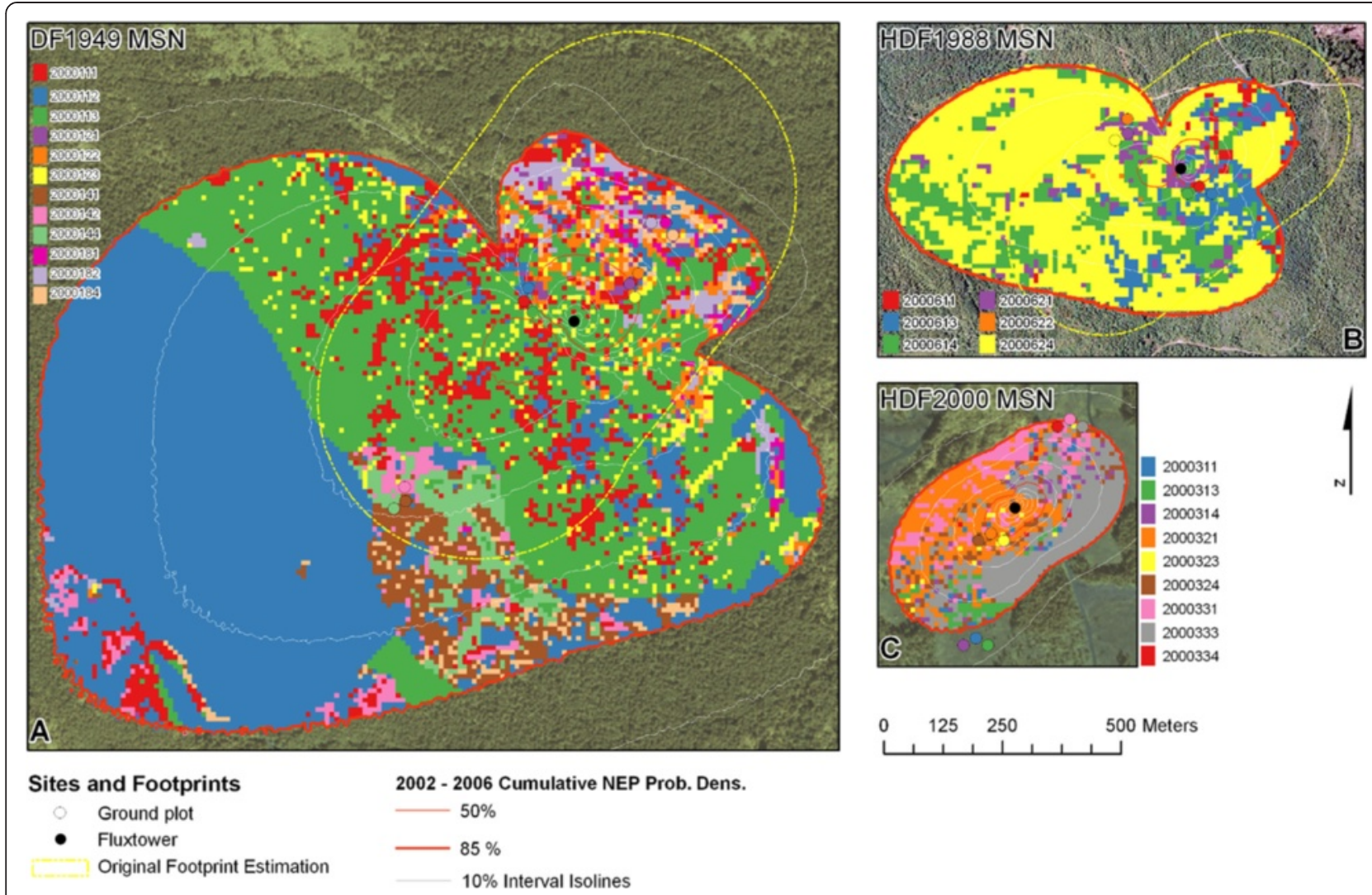

Figure 6 First most similar neighbour (MSN) sample plots demonstrate the patterns of spatial variability for $\mathbf{A}$ ) the near rotation stand, B) juvenile stand, C) recent clearcut. Background imagery is pan-sharpened 2004 Quickbird for A and C, and true-colour orthophoto for B.

FPW, but less than 1 standard deviation different. For $\Delta \mathrm{C}_{2}$ total, all estimates were within 1 standard deviation.

Comparing the $\Delta \mathrm{C}_{2}$ and $\Sigma \mathrm{NEP}$ methods at the juvenile stands, HDF88 was compared with measurements from the flux tower installed at the site, and HDF90 was compared with CBM-CFS3 model output. While the two stands were similar in seral stage, species composition, and stand history, there were differences in stand composition. For example, HDF88 had higher live C stocks, in particular, live stem $\mathrm{C}$, understory stem $\mathrm{C}$, and total stem $\mathrm{C}$. In addition, HDF88 had larger detritus $\mathrm{C}$ stocks including stumps $\mathrm{C}$, large woody debris $\mathrm{C}$, and total detritus $\mathrm{C}$. The stand variability at HDF88 was also greater than at HDF90 indicated by the large standard deviations compared to the means. Given the large amount of spatial variability at HDF88, spatial scaling, and footprint weighting had a notable effect on the amount and sign at this site.

\section{Comparing inventory $\Delta C_{2}$, EC tower $\Sigma$ NEP and CBM-CFS3 ¿NEP}

All methods ranked the near-rotation stand as a sink for $\mathrm{C}$ (net $\mathrm{C}$ uptake), the juvenile stands as a weak sink or weak source (small C uptake or release), and the regenerating clearcut as a source (net $\mathrm{C}$ release). While the ranking was consistent for all methods, there were differences in the magnitude of values for each stand (Table 6).

At the regenerating clearcut, the CBM-CFS3 estimate of $\Sigma$ NEP with footprint weighting converged more closely with the EC tower estimate of $\Sigma \mathrm{NEP}$ than the unweighted estimate, and both were within 1 standard deviation. Evaluating the yearly means (Figure 8a), demonstrated that footprint weighting improved convergence between the CBM-CFS3 estimate of $\Sigma$ NEP and the EC flux $\Sigma$ NEP. This was primarily due to less weighting for patches of uncut forest in the periphery of the flux footprint (Figure 4).

At the juvenile sites, CBM-CFS3 $\Sigma$ NEP indicated that HDF90 was a weak sink (net C uptake) and EC tower $\Sigma$ NEP indicated that HDF88 was a weak source (net C release) (Tables 3 and 6). At the near rotation stand, the estimates of $\Sigma$ NEP from CBM-CFS3 were higher than the EC flux tower $\Sigma$ NEP, with the footprint weighted estimate being the highest. Considering the means of $\Sigma$ NEP from CBM-CFS3 on a yearly basis, footprint weighting decreased convergence with the EC flux tower measurement of $\Sigma$ NEP (Figure 8b). 


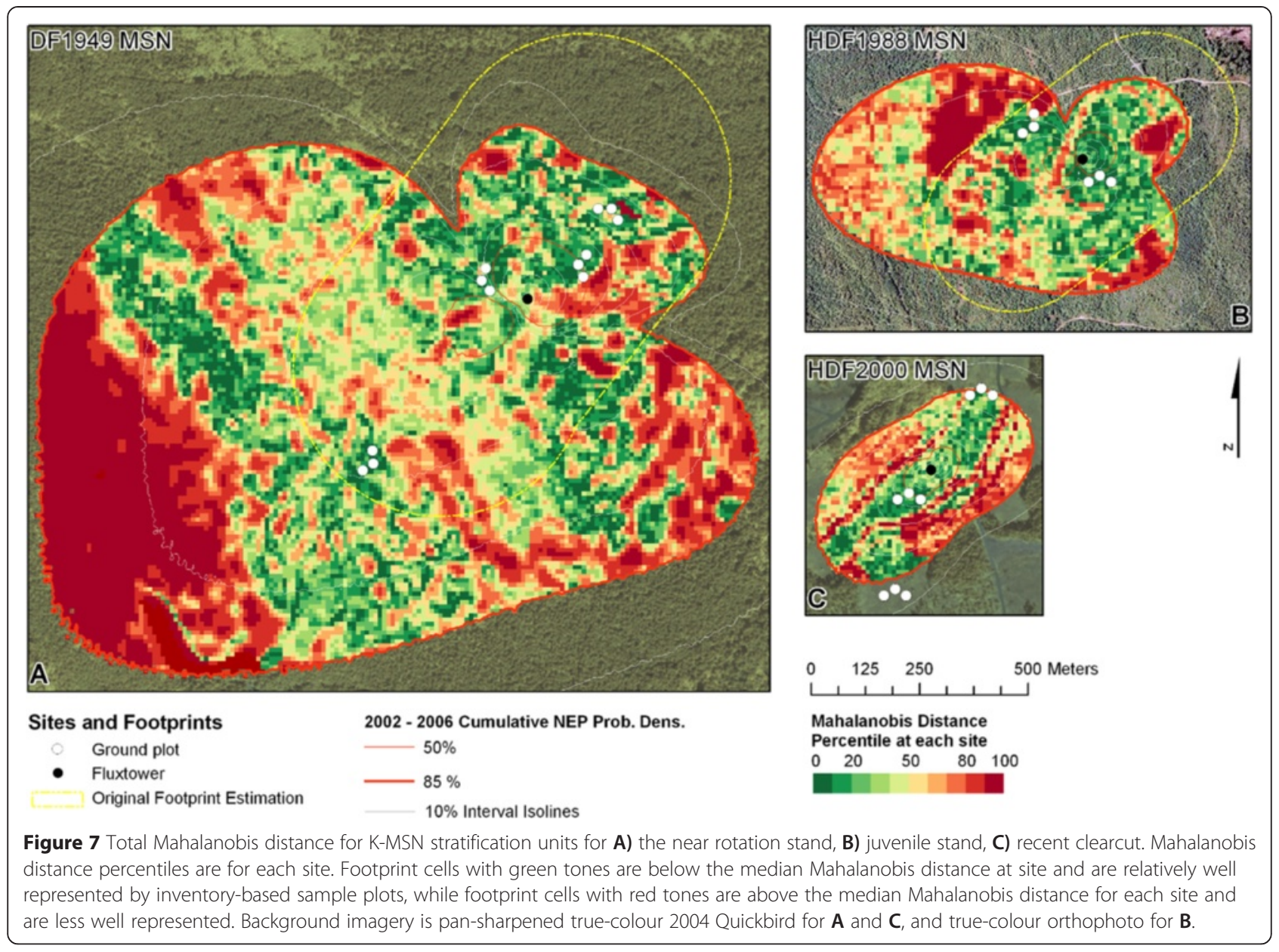

Table 5 Site mean $\left( \pm\right.$ RMSD) changes in live biomass $\left(\Delta C_{L}\right)$ and detrital $\left(\Delta C_{D 2}\right) C$ stocks calculated using three most similar neighbours classification (K-MSN), and K-MSN with footprint weighting means (K-MSN FPW) of plots for sites with flux-towers

\begin{tabular}{|c|c|c|c|c|c|c|c|}
\hline \multirow[b]{2}{*}{ Pool } & \multirow[b]{2}{*}{ Component } & \multicolumn{2}{|l|}{ DF49 } & \multicolumn{2}{|l|}{ HDF88 } & \multicolumn{2}{|l|}{ HDFOO } \\
\hline & & K-MSN & K-MSN FPW & K-MSN & K-MSN FPW & K-MSN & K-MSN FPW \\
\hline \multirow[t]{7}{*}{ Live } & $\Delta C_{L}$ Foliage & $0.1 \pm 1.7$ & $0.2(0.4) \pm 1.7$ & $1.3 \pm 2$ & $1.3(0.3) \pm 2$ & $0.2 \pm 0.9$ & $0.1 \pm 0.9$ \\
\hline & $\Delta C_{L}$ Branches & $0.9 \pm 1.6$ & $1(0.6) \pm 1.6$ & $1.9 \pm 1.3$ & $1.8(0.6) \pm 1.3$ & $0.1 \pm 1.1$ & $0 \pm 1.1$ \\
\hline & $\Delta \mathrm{C}_{\mathrm{L}}$ Bark & $1.1 \pm 1.5$ & $1.1(0.4) \pm 1.5$ & $1 \pm 1.7$ & $1(0.3) \pm 1.7$ & $0.1 \pm 0.8$ & $0 \pm 0.8$ \\
\hline & $\Delta \mathrm{C}_{\mathrm{L}}$ Stem & $6.7 \pm 1.4$ & $6.1(2.2) \pm 1.4$ & $4.4 \pm 1.7$ & $4.2(1.2) \pm 1.7$ & $0.4 \pm 0.9$ & $0.1 \pm 0.9$ \\
\hline & $\Delta C_{L}$ Understory & $1.8 \pm 1$ & $2.5(2.3) \pm 1$ & $-0.9 \pm 0.8$ & $-1.7(5.2) \pm 0.8$ & $0.8 \pm 1.3$ & $0.6 \pm 1.3$ \\
\hline & $\Delta C_{L}$ Roots & $2 \pm 1.5$ & $1.9(0.8) \pm 1.5$ & $4.3 \pm 2$ & $4.4(0.6) \pm 2$ & $0.3 \pm 1.1$ & $0.1 \pm 1.1$ \\
\hline & $\Delta \mathrm{C}_{\text {LTotal }}$ & $12.8 \pm 1.6$ & $12.8(3) \pm 1.6$ & $11.9 \pm 0.8$ & $10.9(7.2) \pm 0.8$ & $1.8 \pm 0.8$ & $1 \pm 0.8$ \\
\hline \multirow[t]{6}{*}{ Detritus } & $\Delta C_{D 2}$ Standing Dead & $-5.7 \pm 1.2$ & $-8.1(16.1) \pm 1.2$ & $0.1 \pm 1.3$ & $-0.7(0.4) \pm 1.2$ & $0 \pm 1.4$ & $0 \pm 1.4$ \\
\hline & $\Delta \mathrm{C}_{\mathrm{D} 2}$ Stumps & $-0.5 \pm 1.1$ & $-0.5(0.1) \pm 1.1$ & $-0.6 \pm 1.2$ & $-3.5(1.1) \pm 1.9$ & $-0.7 \pm 1.3$ & $-0.8 \pm 1.3$ \\
\hline & $\Delta C_{D 2}$ Large Woody Debris & $3.5 \pm 0.9$ & $6.3(13.7) \pm 0.9$ & $-3.5 \pm 1.9$ & $-0.1(0.2) \pm 1.1$ & $-1.5 \pm 0.3$ & $-1.5 \pm 0.3$ \\
\hline & $\Delta C_{D 2}$ Find Woody Debris & $0.6 \pm 1.4$ & $0.2(0.8) \pm 1.4$ & $-0.1 \pm 1.1$ & $-6.9(4.3) \pm 1.5$ & $-2 \pm 1.3$ & $-1.6 \pm 1.3$ \\
\hline & $\Delta \mathrm{C}_{\mathrm{D} 2}$ Litter & $7.1 \pm 0.9$ & $8.7(2.5) \pm 0.9$ & $-6.2 \pm 1.5$ & $-0.2(11.2) \pm 1.6$ & $-6.1 \pm 1.3$ & $-4.8 \pm 1.3$ \\
\hline & $\Delta \mathrm{C}_{\mathrm{D} 2 \mathrm{Total}}$ & $5 \pm 1.5$ & & $-10.3 \pm 1.6$ & $1.3(0.3) \pm 2$ & $-10.4 \pm 1.3$ & $-8.7 \pm 1.3$ \\
\hline Total & $\Delta C_{2}=\Delta C_{\text {LTotal }}+\Delta C_{D 2 \text { Total }}$ & $17.8 \pm 1.2$ & $19.5(5.9) \pm 1.5$ & $1.6 \pm 1.2$ & $-0.2 \pm 1.2$ & $-8.6 \pm 1.3$ & $-7.7 \pm 1.3$ \\
\hline
\end{tabular}

The Root Mean Square Difference (RMSD) is presented as an estimate of spatial estimation error. 
Table 6 Comparisons of inventory-based site $C$ stock changes $\left(\Delta C_{2}\right)$ determined from plot means (live biomass and detrital fluxes), K-MSN scaling mean (standard deviation), and K-MSN with footprint weighting (K-MSN FPW) mean (standard deviation) to estimates of ENEP from flux towers and ENEP from CBM-CFS3 for the (a) 4-year period 2003-2006 Mg C ha-1 and the (b) mean annual value for each method in $\mathrm{Mg} \mathrm{C} \mathrm{ha}^{-1} \mathrm{yr}^{-1}$

\begin{tabular}{|c|c|c|c|c|}
\hline \multirow{2}{*}{$\begin{array}{l}\text { a) } \\
\text { Method }\end{array}$} & \multicolumn{4}{|l|}{ Site } \\
\hline & DF49 & HDF90 & HDF88 & HDFOO \\
\hline$\Delta \mathrm{C}_{2}$ Mean & $19.4(7.2)$ & $2.0(8.5)$ & $-2.5(13.3)$ & $-10.1(8.2)$ \\
\hline$\Delta \mathrm{C}_{2} \mathrm{~K}-\mathrm{MSN}$ & $17.8(5.8) \pm 1.2$ & na/ & $1.6(11.7) \pm 1.2$ & $-8.6(5.0) \pm 1.3$ \\
\hline$\Delta C_{2}$ K-MSN FPW & $19.5(5.9) \pm 1.2$ & na/ & $-0.2(11.2) \pm 1.2$ & $-7.7(3.5) \pm 1.3$ \\
\hline ¿NEP Flux Tower & $13.6 \pm 3.6$ & na/ & -1.9 & -20.1 \\
\hline$\sum$ NEP CBM-CFS3* & 18.9 & $2.0^{*}$ & na/ & -11.5 \\
\hline ¿NEP CBM-CFS3 FPW & 24.1 & na/ & na/ & -17.9 \\
\hline b) & \multicolumn{4}{|l|}{ Site } \\
\hline Method & DF49 & HDF90 & HDF88 & HDFOO \\
\hline$\Delta \mathrm{C}_{2}$ Mean & $4.9(1.8)$ & $0.5(2.1)$ & $-0.63(3.3)$ & $-2.5(2.0)$ \\
\hline$\Delta \mathrm{C}_{2} \mathrm{~K}-\mathrm{MSN}$ & $4.5(1.5) \pm 1.2$ & na/ & $0.4(2.9) \pm 1.2$ & $-2.2(1.2) \pm 1.3$ \\
\hline$\Delta C_{2}$ K-MSN FPW & $4.9(1.5) \pm 1.2$ & na/ & $-0.1(2.8) \pm 1.2$ & $-1.9(1.9) \pm 1.3$ \\
\hline ¿NEP Flux Tower & $3.4 \pm 0.9$ & na/ & -0.5 & -5.0 \\
\hline ¿NEP CBM-CFS3* & 4.7 & $0.5^{*}$ & na/ & -2.9 \\
\hline ¿NEP CBM-CFS3 FPW & 6.0 & na/ & na/ & -4.47 \\
\hline
\end{tabular}

*average of all grid cells encompassing the six plots $2003-2006$. na - not available or not applicable.

At the regenerating clearcut, unweighted $\Delta C_{2}$ was within 1 standard deviation of the CBM-CFS3 estimates of $\Sigma$ NEP, and closest to unweighted CBM-CFS3 $\Sigma$ NEP. The unweighted mean of $\Delta C_{2}, \Delta C_{2}$ K-MSN, and $\Delta C_{2}$ K-MSN FPW were greater than 1 standard deviation higher than the EC flux tower estimate of $\Sigma$ NEP. $\Delta C_{2}$ K-MSN was within 1 standard deviation of the CBM-CFS3 unweighted $\Sigma$ NEP. Both $\Delta \mathrm{C}_{2} \mathrm{~K}-\mathrm{MSN}$ and $\Delta \mathrm{C}_{2}$ K-MSN FPW were greater than 1 standard deviation higher than $\Sigma$ NEP CBM-CFS 3 FPW (Table 6).

At the juvenile stands, all estimates $\Delta C_{2}$ were within 1 standard deviation of the estimates of $\Sigma$ NEP. At HDF90, the unweighted estimate of $\Delta C_{2}$ matched $\Sigma$ NEP CBMCFS3. At HDF88, the unweighted mean of ground plots was the closest to the EC tower measurements of $\Sigma \mathrm{NEP}$, while the $\Delta C_{2}$ K-MSN had a different sign (indicating a small source), and the K-MSN $\Delta \mathrm{C}_{2}$ FPW had the same sign as $\Delta C_{2}$ unweighted (Table 6).

At the near-rotation stand, all estimates of $\Delta C_{2}$ were within 1 standard deviation of all estimates of $\Sigma \mathrm{NEP}$. The estimates of $\Delta C_{2}$ (and CBM-CFS3 $\Sigma$ NEP) higher than the EC flux tower measurements of $\Sigma$ NEP (Table 6).

\section{Discussion}

Several approaches can be used to compare forest inventory data with EC $\Sigma$ NEP. For example, several authors have used measurements or estimates of soil and detritus respiration in combination with inventory measurements of overstory productivity (Law et al. 2001; Ehman et al. 2002; Kolari et al. 2004; Black et al. 2005). In the present study, comparisons were based on measurements of $\triangle \mathrm{C}$ which were higher than EC $\Sigma \mathrm{NEP}$. Black et al. (2005) also found a divergence between inventory measurements of $\Delta C$ (including $\Delta C_{S}$ measurements) and EC $\Sigma$ NEP, with $\Delta C$ higher than EC $\Sigma$ NEP; however, they also calculated $\Sigma \mathrm{NEP}$ using measurements of heterotrophic respiration combined with biometric estimates of NPP, and found that the bias was not observed. They concluded that $\Delta \mathrm{C}$ systematically overestimated NEP due to unaccounted decomposition processes and uncertainties in $\Delta C_{S}$. At DF49, Jassal et al. (2010) measured heterotrophic soil respiration in 2007 , which was a major portion of total soil respiration. Including measurements of soil heterotrophic respiration with net primary production estimates from forest inventory may improve convergence with ECflux tower measurements. However, a limitation of taking measurements of soil respiration is that the measurements require long-term collection using special equipment and are not typically collected in traditional forest inventory.

Kolari et al. (2004) found that management practices, such as clearcut harvesting had a large impact on the soil C balance, with clearcut sites soil C sources, while 


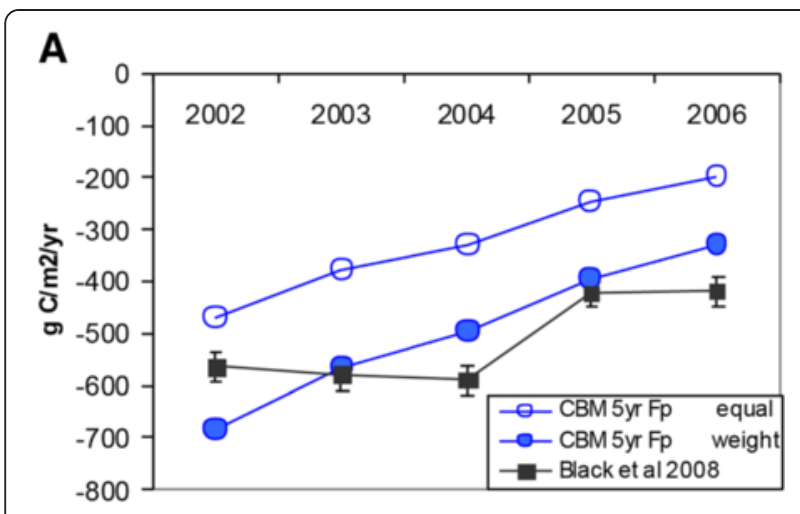

B

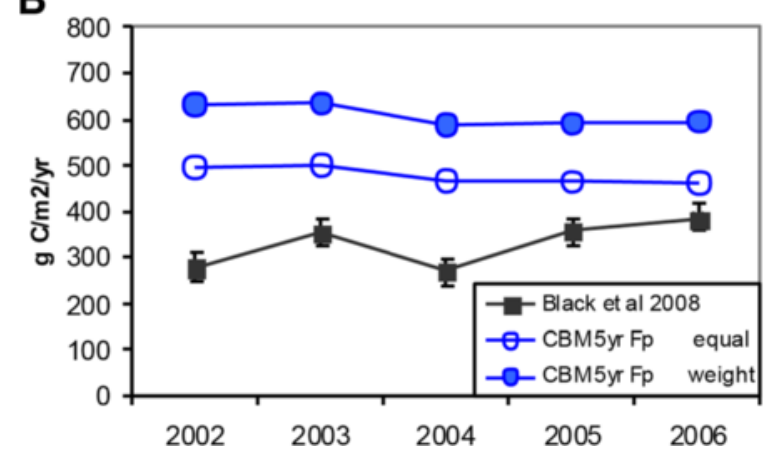

Figure 8 Yearly NEP estimates for CBM-CFS3 and EC flux tower (Black et al. 2008) for (A) the regenerating clearcut and (B) the near-rotation stand. CBM-CFS3 is shown as yearly mean of footprint cells with equal weighting (Fp equal) and weighting by NEP flux probability density distribution (Fp weight).

non-disturbed sites had more stable soil $\mathrm{C}$ balances. In this study, a trend in soil $C$ stocks, with the highest soil $\mathrm{C}$ stocks at the oldest site, and the lowest at the recently disturbed site, was consistent with the trend by seral stage reported by Kolari et al. (2004). For the two similar-aged juvenile stands, since there was no flux tower installed at HDF90 and CBM-CFS3 model runs results were not available at HDF88, a direct comparison was not possible. In addition to the differences in measurement methods, the differences in $\Sigma$ NEP between the two juvenile stands could also be partially attributed to site conditions. Notably, HDF88 had more detrital C stocks, likely leading to larger releases of $\mathrm{C}$ due to decomposition. This was reflected in the more negative $\Delta C_{\mathrm{D} 2}$ at HDF88 compared to HDF90.

For the forest inventory measurement of $\Delta C$ and its components $\Delta C_{L}, \Delta C_{D}$, and $\Delta C_{S}$, differences in procedure, measurement error by field and lab crews, and sample design may introduce error into inventory measurements that may be larger than the magnitude of change in $\mathrm{C}$ stocks over short measurement intervals, such as the 4 year period used in this study. Overall, $\Delta C_{D 1}$ and $\Delta C_{S}$ were much larger than reported in previous studies (e.g. Law et al. 2001), and was much larger than expected given the measured litterfall inputs and estimated decomposition rates. The NFI (2008) calls for 10-year remeasurement intervals, which may be appropriate for trees and detritus, but may be too short for $\Delta \mathrm{C}_{\mathrm{S}}$. In addition, direct use of forest inventory data relies on subjective classification of decay class that can differ from one-field-crew to the next, so utilizing decay and transfer algorithms may reduce the potential effect of these classifications. Developing site-specific allometric equations is labour intensive, destructive, and costly, and therefore uncommon in most studies; however, use of existing relationships can lead to errors due to differences in tree architecture, and wood density. Further, the use of inappropriate allometric equations can be a significant source of error in forest productivity studies (Clark and Brown 2001). The NFI data compilation procedure provided regionally applicable allometric equations; however, the errors in this large pool of equations have not yet been estimated and therefore is a limitation.

The measured changes in $\Delta C_{S}$ were much larger than was expected for a four year period. For example, Law et al. (2001) estimated soil sequestration of $0.7-0.8$ $\mathrm{MgC} \mathrm{ha}{ }^{-1}$ year $^{-1}$ in a Douglas-fir stand and Gielen et al. (2013) found no significant change over an eight-year interval in a Scots pine forest. In other studies by Ehman et al. (2002), Kolari et al. (2004), Miller et al. (2004), Ohtsuka et al. (2007), and Granier et al. (2008) $\Delta C_{S}$ was assumed to be zero over the measurement interval. The large value for $\Delta C_{S}$ in this study may be explained by several factors related to measurement methodology. First, mineral soil bulk densities in the $0-15 \mathrm{~cm}$ layer were assumed not to change and thus the $\mathrm{BD}$ values measured in 2002 were also used in 2006. If the bulk density decreased then the $C_{S}$ change would be overestimated. Second, at the regenerating clearcut and juvenile stands, an increase in fine root mass from 2002 to 2006 included in the $<2 \mathrm{~mm}$ soil fraction could also have accounted for some of the increase in soil C. Third, samples in 2002 were taken by 10-12 cm diameter hole excavations, while samples in 2006 were collected using a $2 \mathrm{~cm}$ diameter soil corer, which, due to compression at the opening of the sample corer, may be biased to soil from shallower depths where $\mathrm{C}$ content is likely higher. Therefore, in this study, measurements of $\Delta C_{S}$ were deemed unreliable, due to the large positive changes in $\Delta C_{S}$, and assumed to be negligible over the four year period and thus not used for subsequent calculations of site level $\Delta C$ and further comparisons. In future work, efforts to reduce any chances of variation in the way the samples are collected and analysed may result in more reliable measurements of $\mathrm{C}$ stock changes. For example, collecting and processing the samples using identical methods at nearly the same locations, or collecting a much larger number of samples to capture a wider range 
of spatial variation could reduce the effect of spatial variability on measurements of $\Delta C_{S}$.

Several authors have applied footprint analysis in an effort to correct for non-homogenous environments, and horizontal advection, for example due to daily upslope or downslope winds, which may introduce bias into the eddy-covariance measurements (Baldocchi 2008). For example, Ehman et al. (2002) used footprints to calculate an estimate of sensor bias given using a vegetation index, and this gave confidence that the sensor measurements were representative of the inventory measurements. Gielen et al. (2013) used a more complex footprint model applied to the processing of NEP data, were fluxes originating outside of the area where inventory measurements were sampled were removed from the NEP estimates. In this study, footprint weighting by ecological attributes and footprint probability density was evaluated where it facilitated comparison between inventory-based measurements of ecosystem $\Delta C$ stocks and tower $\Sigma$ NEP by accounting for fine scale spatial variability in forest structure. The effect of K-MSN classification and footprint weighting had an effect on the estimated site-level values; however, this effect was smaller than differences due to measurement methodology. Notably, applying footprint weighting to the estimation of CBM-CFS3 $\Sigma$ NEP at the regenerating clearcut increased convergence with EC tower $\Sigma \mathrm{NEP}$; however, footprint weighting did not have the same effect for $\Delta C_{2}$. The largest differences observed among methods were seen at the regenerating clearcut, where the inventory approach indicated the site was a much lower source than the $\Sigma$ NEP methods. A possible cause is that the inventory methods did not properly account for $\mathrm{C}$ losses from decomposition of coarse roots from stumps and large woody debris at recently harvested sites, which can be a substantial source of respiration (Janisch et al. 2005). Therefore, if an estimate of stump coarse root decomposition were included in $\triangle \mathrm{CD}_{2}$ it may have increased convergence with the $\Sigma$ NEP estimates. Additionally, the original sample locations were designed to capture the range of conditions in near proximity of the tower (based on interpretation of aerial photographs), and the relationship was similar when scaled up to the site level. Future studies may seek to derive accurate footprint estimates prior to establishing sample plots to ensure they are representative of the broader site conditions. Another more costly alternative is to establish a much greater number of plots in a systematic basis around the tower, to ensure the spatial variation within the tower footprint is adequately captured.

This research highlights how different measurements and approaches for $\mathrm{C}$ accounting include different constraints, and as a result, computations using different data sources may not converge. Each type of measurement has "different strengths and weaknesses, but the combination of multiple measurements and modeling has the potential for refining estimates of $\mathrm{C}$ stocks and fluxes" (Law et al. 2004). For example, eddy-covariance data are temporally detailed, and provide information about daily and seasonal processes. However, the data are less spatially extensive and detailed than the forest inventory data, for example, only three sites were available in this study each covering an area with diverse vegetation within the tower footprint. Measurement error was estimated to be relatively low, on the order of $0.9 \mathrm{Mg} \mathrm{C}^{-1}$ year ${ }^{-1}$ (Morgenstern et al. 2004). In contrast, forest inventory data are more spatially extensive and include detailed measurements of forest attributes. The main constraint for forest inventory data is that they are less temporally detailed (for example, measurements were available at only two points in time), and the error in these measurements may be greater than the expected rate of change over the measurement interval. The inventory plots in this study sampled a broad range of vegetation conditions and provided insight into the representativeness of flux-tower footprints. Estimates of error of 1.2 to $1.3 \mathrm{Mg} \mathrm{C}^{-1}$ were identified relating to spatial representativeness of the inventory plots within the tower footprints. Finally, C budget models are important for understanding landscape scale $C$ processes. Since these models depend on numerous coefficients, algorithms and assumptions, it is valuable to compare model outputs with EC flux and inventory measurements to assess their performance and evaluate their behaviour. Considering all of these approaches together, the relative strengths and limitation of each approach can be taken into account in evaluating the suitability of each type of measurement at varying spatial and temporal scales.

\section{Conclusions}

The comparison of $\triangle \mathrm{C}$ from inventory measurements with $\Sigma$ NEP from CBM-CFS3 and EC flux-tower measurements demonstrated an agreement among the methods in trends across stand seral stage; however, due to differences in the measurement approaches, there was some divergence in the results. Convergence amongst methods was closest for the juvenile sites (HDF90 and HDF88), which were in transition from $\mathrm{C}$ source- to sink. At the most recently harvested site (HDF00), the EC flux $\Sigma$ NEP and CBM CFS3 $\Sigma$ NEP indicated that the site was a greater source of $\mathrm{C}$ over the time period than $\Delta \mathrm{C}$ from inventory methods. At the near-rotation site the inventory $\Delta C_{2}$ method, unweighted CBM CFS3 $\Sigma$ NEP and EC flux $\Sigma$ NEP also converged.

Each of the measurement methods had advantages and limitations. For example, while EC flux towers provide temporally rich data, they had limited spatial coverage. Obtaining $\Delta \mathrm{C}$ using forest inventory measurements included several challenges such as the consistency of 
data collected over long time intervals, small changes in $\Delta \mathrm{C}$ compared to uncertainty in the measurements, and insufficient measurement of processes such as decomposition of all detrital pools. Forest inventory data are available over broad areas; therefore methods that combine measurements with estimates of decomposition are needed to provide information over a regional scale. Footprint analysis using the spatial predictors from remote sensing and topography can give confidence that sample locations represent broader area site conditions. Considering the advantages and constraints of each type of measurement is helpful in choosing appropriate measurement methods at varying spatial and temporal scales.

\section{Competing interests}

The authors declare that they have no competing interests.

\section{Authors' contributions}

CJF set research objectives, devised and undertook analysis, and composed the manuscript. JAT set research objectives, directed the collection and synthesis of field data, summarized output from CBM-CFS3 runs, advised analysis, assisted with manuscript composition, and provided extensive editorial work on the manuscript. NCC advised on research objectives, advised analysis, and assisted with manuscript composition. BC advised the footprint analysis, and provided commentary on manuscript. TAB advised on research objectives, advised the analysis, and provide extensive review and commentary throughout the work. All authors read and approved the final manuscript.

\section{Acknowledgements}

We thank Bob Ferris, Frank Eichel, and Glenda Russo of the Canadian Forest Service and staff of B.A. Blackwell and Associates for their help processing and collecting National Forest-inventory-style ground plot data. We also thank François Gougeon, CFS, for determining canopy tree density values for the sites and to Graham Stinson, CFS, for the CBM-CFS3 output files used in Wang et al. (2011). We thank the UBC Land and Food Systems Biometeorology and Soil Physics Group, in particular Paul Jassal, Praveena Krishnan, Kai Morgenstern, and Elyn Humphreys for their work processing EC flux data, and Zoran Nesic, Dominic Lessard, Andrew Sauter, and Andrew Hum for their work running and maintaining the EC flux tower sites. We also thank Mark Johnson for his comments and suggestions. Funding for this study was provided by the Canadian Forest Service Pacific Forestry Centre Graduate Student Award, a CFCAS grant to the Canadian Carbon Program (CCP), and Natural Sciences and Engineering Research Council of Canada (NSERC) Discovery Grant to NCC. The LiDAR data were acquired by Benoit St-Onge of the University of Quebec at Montreal as part of an ongoing collaborative project with funds provided by NSERC and BIOCAP.

\section{Author details}

'Department of Forest Resources Management, University of British Columbia, 2424 Main Mall, Vancouver, BC V6T 1Z4, Canada. ${ }^{2}$ Canadian Forest Service (Pacific Forestry Centre), Natural Resources Canada, 506 Burnside Road West, Victoria, BC V8Z 1M5, Canada. ${ }^{3}$ Faculty of Land and Food Systems, University of British Columbia, 2357 Main Mall, Vancouver, BC V6T 1Z4, Canada. ${ }^{4}$ Department of Biology, University of Victoria, PO Box 1700, Station CSC, Victoria, BC V8W 2Y2, Canada.

\section{Received: 18 December 2014 Accepted: 21 April 2015}

Published online: 07 May 2015

\section{References}

Babst F, Bouriaud O, Papale D, Gielen B, Janssens I, Nikinmaa E, Ibrom A, Wu J, Bernhofer C, Köstner B, Grünwald T, Seufert G, Ciais P, Frank D (2014) Above-ground woody carbon sequestration measured from tree rings is coherent with net ecosystem productivity at five eddy-covariance sites. New Phytol 201:1289-1303, doi: 10.1111/nph.12589
Bailey JD, Mayrsohn C, Doescher PS, St Pierre E, Tappeiner JC (1998) Understory vegetation in old and young Douglas-fir forests of western Oregon. For Ecol Manage 112:289-302

Baldocchi DD (2008) "Breathing" of the terrestrial biosphere: lessons learned from a global network of carbon dioxide flux measurement systems. Aust J Bot 56:1, doi:10.1071/BT07151

Barford CC, Wofsy SC, Goulden ML, Munger JW, Pyle EH, Urbanski SP, Hutyra L, Saleska SR, Fitzjarrald D, Moore K (2001) Factors controlling long- and short-term sequestration of atmospheric CO2 in a mid-latitude forest. Science 294:1688-1691, doi:10.1126/science.1062962

Black K, Bolger T, Davis P, Nieuwenhuis M, Reidy B, Saiz G, Tobin B, Osborne B (2005) Inventory and eddy covariance-based estimates of annual carbon sequestration in a Sitka spruce (Picea sitchensis (Bong.) Carr.) forest ecosystem. Eur J For Res 126:167-178, doi:10.1007/s10342-005-0092-4

Black TA, Fredeen A, Jassal R (2008) Carbon Sequestration in British Columbia's Forests and Management Options. University of Victoria, Victoria, BC, White paper. Pacific Institute for Climate Solutions

Brown JK (1971) A planar intersect method for sampling fuel volume and surface area. For Sci 17:96-102

Chen B, Chen JM, Mo G, Black TA, Worthy DEJ (2008) Comparison of regional carbon flux estimates from $\mathrm{CO} 2$ concentration measurements and remote sensing based footprint integration. Global Biogeochem Cycles. doi:10.1029/2007GB003024

Chen BB, Black TA, Coops NC, Hilker T, Trofymow JA, Morgenstern K, Black AT (2009) Assessing tower flux footprint climatology and scaling between remotely sensed and eddy covariance measurements. Boundary-Layer Meteorol 130:137-167, doi:10.1007/s10546-008-9339-1

Clark D, Brown S (2001) Measuring net primary production in forests: concepts and field methods. Ecol Appl 11:356-370

Coops NC, Hilker T, Wulder MA, St-Onge B, Newnham GJ, Siggins A, Trofymow JA (2007) Estimating canopy structure of Douglas-fir forest stands from discretereturn LiDAR. Trees-Structure Funct 21:295-310. doi:10.1007/s00468-006-0119-6

Crookston NL, Finley AO (2008) yalmpute: an R package for kNN imputation. J Stat Softw 23(10):1-16

Curtis P, Hanson P, Bolstad P, Barford C, Randolph J, Schmid H, Wilson K (2002) Biometric and eddy-covariance based estimates of annual carbon storage in five eastern North American deciduous forests. Agric For Meteorol 113:3-19, doi:10.1016/S0168-1923(02)00099-0

Dixon RK, Solomon AM, Brown S, Houghton RA, Trexier MC, Wisniewski J (1994) Carbon pools and flux of global forest ecosystems. Science 263:185-190, doi:10.1126/science.263.5144.185

Ehman JL, Schmid HP, Grimmond CSB, Randolph JC, Hanson PJ, Wayson CA, Cropley FD (2002) An initial intercomparison of micrometeorological and ecological inventory estimates of carbon exchange in a mid-latitude deciduous forest. Glob Chang Biol 8:575-589, doi:10.1046/j.1365-2486.2002.00492.x

Ferster CJ, Trofymow JA, Coops NC, Chen B, Black TA, Gougeon FA (2011) Determination of ecosystem carbonstock distributions in the flux footprint of an eddy-covariance tower in a coastal forest in British Columbia. Can J For Res 41:1380-1393, doi:10.1139/X11-055

Gielen B, De Vos B, Campioli M, Neirynck J, Papale D, Verstraeten A, Ceulemans R, Janssens IA (2013) Biometric and eddy covariance-based assessment of decadal carbon sequestration of a temperate Scots pine forest. Agric For Meteorol 174:135-143, doi:10.1016/j.agrformet.2013.02.008

Gillis M, Omule A, Brierley T (2005) Monitoring Canada's forests: the national forest inventory. For Chron 81:214-221

Göckede M, Rebmann C, Foken T (2004) A combination of quality assessment tools for eddy covariance measurements with footprint modelling for the characterisation of complex sites. Agric For Meteorol 127:175-188, doi:10.1016/j.agrformet.2004.07.012

Gougeon F (1995) A crown-following approach to the automatic delineation of individual tree crowns in high spatial resolution aerial images. Can J Remote Sens 21:274-284

Gough C, Vogel C, Schmid H, Su H, Curtis P (2008) Multi-year convergence of biometric and meteorological estimates of forest carbon storage. Agric For Meteorol 148:158-170, doi:10.1016/j.agrformet.2007.08.004

Granier A, Ceschia E, Damesin C, Dufrene E, Epron D, Gross P, Lebaube S, Le Dantec V, Le Goff N, Lemoine D, Lucot E, Ottorini JM, Pontailler JY, Saugier B (2000) The carbon balance of a young Beech forest. Funct Ecol 14:312-325, doi:10.1046/j.1365-2435.2000.00434.x

Granier A, Bréda N, Longdoz B, Gross P, Ngao J (2008) Ten years of fluxes and stand growth in a young beech forest at Hesse, North-eastern France. Ann For Sci 65:704-704, doi:10.1051/forest 
Grant RF, Black TA, Humphreys ER, Morgenstern K (2007) Changes in net ecosystem productivity with forest age following clearcutting of a coastal Douglas-fir forest: testing a mathematical model with eddy covariance measurements along a forest chronosequence. Tree Physiol 27:115-131

Green RN, Klinka K (1994) A Field Guide to Site Identification and Interpretation for the Vancouver Forest Region. Land Management Handbook Number 28. British Columbia Ministry of Forests, Research Program, Victoria, BC

Humphreys ER, Black TA, Morgenstern K, Cai T, Drewitt GB, Nesic Z, Trofymow JA (2006) Carbon dioxide fluxes in coastal Douglas-fir stands at different stages of development after clearcut harvesting. Agric For Meteorol 140:6-22, doi:10.1016/j.agrformet.2006.03.018

Janisch JE, Harmon ME, Chen H, Fasth B, Sexton J (2005) Decomposition of coarse woody debris originating by clearcutting of an old-growth conifer forest. Ecoscience 12:151-160, doi:10.2980/i1195-6860-12-2-151.1

Janzen HH (2005) Soil carbon: a measure of ecosystem response in a changing world? Can J Soil Sci 85:467-480

Jassal RS, Black TA, Trofymow JA, Roy R, Nesic Z (2010) Soil $\mathrm{CO}_{2}$ and $\mathrm{N}_{2} \mathrm{O}$ flux dynamics in a nitrogen-fertilized Pacific Northwest Douglas-fir stand. Geoderma 157:118-125, doi:10.1016/j.geoderma.2010.04.002

Jungen J (1985) Soils of Southern Vancouver Island. Victoria, BC

Kolari P, Jukka P, Rannik U, Hannu I, Pertti H, Berninger F (2004) Carbon balance of different aged Scots pine forests in Southern Finland. Glob Chang Biol 10:1106-1119, doi:10.1111/j.1365-2486.2004.00797.x

Kominami Y, Jomura M, Dannoura M, Goto Y, Tamai K, Miyama T, Kanazawa Y, Kaneko S, Okumura M, Misawa N, Hamada S, Sasaki T, Kimura H, Ohtani Y (2008) Biometric and eddy-covariance-based estimates of carbon balance for a warm-temperate mixed forest in Japan. Agric For Meteorol 148:723-737, doi:10.1016/j.agrformet.2008.01.017

Krishnan P, Black TA, Jassal RS, Chen B, Nesic Z (2009) Interannual variability of the carbon balance of three different-aged Douglas-fir stands in the Pacific Northwest. J Geophys Res 114:G04011, doi:10.1029/2008JG000912

Kurz W, Apps M, Banfield E, Stinson G (2002) Forest carbon accounting at the operational scale. For Chron 78:672-679

Kurz WA, Dymond CC, White TM, Stinson G, Shaw CH, Rampley GJ, Smyth C, Simpson BN, Neilson ET, Trofymow JA, Metsaranta J, Apps MJ (2009) CBMCFS3: a model of carbon-dynamics in forestry and land-use change implementing IPCC standards. Ecol Modell 220:480-504, doi:10.1016/ j.ecolmodel.2008.10.018

Lambert M-C, Ung C-H, Raulier F (2005) Canadian national tree aboveground biomass equations. Can J For Res 35:1996-2018, doi:10.1139/x05-112

Landsberg JJ, Waring RH (1997) A generalised model of forest productivity using simplified concepts of radiation-use efficiency, carbon balance and partitioning For Ecol Manage 95:209-228, doi:10.1016/S0378-1127(97)00026-1

Law B, Thornton P, Irvine J (2001) Carbon storage and fluxes in ponderosa pine forests at different developmental stages. Glob Chang Biol 7:755-777

Law BE, Turner D, Campbell J, Sun OJ, Van Tuyl S, Ritts WD, Cohen WB (2004) Disturbance and climate effects on carbon stocks and fluxes across Western Oregon USA. Glob Chang Biol 10:1429-1444, doi:10.1111/j.13652486.2004.00822x

Leclerc M, Thurtell G (1990) Footprint prediction of scalar fluxes using a Markovian analysis. Boundary-Layer Meteorol 52(3):247-258

Li Z, Kurz WA, Apps MJ, Beukema SJ (2003) Belowground biomass dynamics in the Carbon Budget Model of the Canadian Forest Sector: recent improvements and implications for the estimation of NPP and NEP. Can J For Res 33:126-136, doi:10.1139/×02-165

Mahalanobis P (1936) On the generalized distance in statistics. Proc Natl Inst Sci 12:49-55

Matthews G (1993) The carbon content of trees. Forestry Commission Technical Paper, vol. 4. Forestry Commission, London

Miller SD, Goulden ML, Menton MC, da Rocha HR, de Freitas HC, Figueira AMES, de Sousa CA D (2004) Biometric and micrometeorological measurements of tropical forest carbon balance. Ecol Appl 14:114-126, doi:10.1890/02-6005

Morgenstern K, Andrew Black T, Humphreys ER, Griffis TJ, Drewitt GB, Cai T, Nesic Z, Spittlehouse DL, Livingston NJ (2004) Sensitivity and uncertainty of the carbon balance of a Pacific Northwest Douglas-fir forest during an El Niño/La Niña cycle. Agric For Meteorol 123:201-219, doi:10.1016/ j.agrformet.2003.12.003

NFI (2008) Canada's National Forest Inventory - Ground Sampling Guidelines. Natural Resources Canada, Canadian Forest Service, Victoria, BC, [Electronic Resource]. Available: https://nfi.nfis.org/documentation/ground_plot/Gp_ guidelines_v5.0.pdf. Accessed 13 April 2015
Ohtsuka T, Mo W, Satomura T, Inatomi M, Koizumi H (2007) Biometric based carbon flux measurements and net ecosystem production (NEP) in a temperate deciduous broad-leaved forest beneath a flux tower. Ecosystems 10:324-334, doi:10.1007/s10021-007-9017-z

R Development Core Team (2011) R: a language and environment for statistical computing. R Foundation for Statistical Computing, Vienna, Austria, URL http://www.R-project.org/

Richardson AD, Hollinger DY (2007) A method to estimate the additional uncertainty in gap-filled NEE resulting from long gaps in the $\mathrm{CO} 2$ flux record. Agric For Meteorol 147:199-208, doi:10.1016/j.agrformet.2007.06.004

Roberts D, Cooper S (1989) Concepts and techniques of vegetation mapping. In: Ferguson D, Morgan P, Johnson FD (eds) Land classifications based on vegetation: applications for resource management. USDA Forest Service General Technical Report: INT-257; USDA Forest Service Intermountain Forest and Range Experiment Station, Ogden, UT, USA, pp 90-96

Schmid H (2002) Footprint modeling for vegetation atmosphere exchange studies: a review and perspective. Agric For Meteorol 113:159-183, doi:10.1016/S0168-1923(02)00107-7

Schmid HP, Lloyd CR (1999) Spatial representativeness and the location bias of flux footprints over inhomogeneous areas. Agric For Meteorol 93:195-209, doi:10.1016/S0168-1923(98)00119-1

Schulze ED, Hogberg P, Van Oene H, Persson T, Harrison A, Read D, Kjoller A, Matteucci G (2000) Interactions Between the Carbon and Nitrogen Cycles and the Role of Biodiversity: A Synopsis of a Study Along a North-south Transect Through Europe. In: Schulze ED (ed) Carbon and Nitrogen Cycling in European Forest Ecosystems. Springer, Heidelberg, pp 468-491

Smyth C, Trofymow JA, Kurz W (2010) Decreasing Uncertainty in CBM-CFS3 Estimates of Forest Soil Carbon Sources and Sinks Through use of Long-Term Data from the Canadian Intersite Decomposition Experiment. Information Report BC-X-422. Natural Resources Canada, Canadian Forest Service, Pacific Forestry Centre, Victoria, BC

Stage AR, Crookston NL (2007) Partitioning error components for accuracyassessment of near-neighbor methods of imputation. For Sci 53:62-72

Ter-Mikaelian M (1997) Biomass equations for sixty-five North American tree species. For Ecol Manage 97:1-24, doi:10.1016/S0378-1127(97)00019-4

Theede AD (2007) Biometric and Eddy-Covariance Estimates of Ecosystem Carbon Storage at Two Boreal Forest Stands in Saskatchewan: 1994-2004. University of Saskatchewan, MSc thesis

Trofymow JA, Stinson G, Kurz WA (2008) Derivation of a spatially explicit 86-year retrospective carbon budget for a landscape undergoing conversion from old-growth to managed forests on Vancouver Island, BC. For Ecol Manage 256:1677-1691, doi:10.1016/j.foreco.2008.02.056

Wang Z, Grant RF, Arain MA, Chen BN, Coops N, Hember R, Kurz WA, Price DT, Stinson G, Trofymow JA, Yeluripati J, Chen Z (2011) Evaluating weather effects on interannual variation in net ecosystem productivity of a coastal temperate forest landscape: a model intercomparison. Ecol Modell 222:3236-3249, doi:10.1016/j.ecolmodel.2011.06.005

Yashiro Y, Lee N-YM, Ohtsuka T, Shizu Y, Saitoh TM, Koizumi H (2010) Biometricbased estimation of net ecosystem production in a mature Japanese cedar (Cryptomeria japonica) plantation beneath a flux tower. J Plant Res 123:463-472, doi:10.1007/s10265-010-0323-8

\section{Submit your manuscript to a SpringerOpen ${ }^{\odot}$ journal and benefit from:}

- Convenient online submission

- Rigorous peer review

- Immediate publication on acceptance

- Open access: articles freely available online

- High visibility within the field

- Retaining the copyright to your article

Submit your next manuscript at $>$ springeropen.com 